\title{
A large 28S rDNA-based phylogeny confirms the limitations of established morphological characters for classification of proteocephalidean tapeworms (Platyhelminthes, Cestoda)
}

\author{
Alain de Chambrier', Andrea Waeschenbach², Makda Fisseha', \\ Tomáš Scholz ${ }^{3}$, Jean Mariaux ${ }^{1,4}$
}

I Natural History Museum of Geneva, CP 6434, CH - 1211 Geneva 6, Switzerland 2 Natural History Museum, Life Sciences, Cromwell Road, London SW7 5BD, UK 3 Institute of Parasitology, Biology Centre of the Czech Academy of Sciences, Branišovská 31, 37005 České Budějovice, Czech Republic 4 Department of Genetics and Evolution, University of Geneva, CH - 1205 Geneva, Switzerland

Corresponding author: Jean Mariaux (jean.mariaux@ville-ge.ch)

Academic editor: B. Georgiev | Received 8 February 2015 | Accepted 23 March 2015 | Published 27 April 2015

http://zoobank.org/DC56D24D-23A1-478F-AED2-2EC77DD21E79

Citation: de Chambrier A, Waeschenbach A, Fisseha M, Scholz T and Mariaux J (2015) A large 28S rDNA-based phylogeny confirms the limitations of established morphological characters for classification of proteocephalidean tapeworms (Platyhelminthes, Cestoda). ZooKeys 500: 25-59. doi: 10.3897/zookeys.500.9360

\begin{abstract}
Proteocephalidean tapeworms form a diverse group of parasites currently known from 315 valid species. Most of the diversity of adult proteocephalideans can be found in freshwater fishes (predominantly catfishes), a large proportion infects reptiles, but only a few infect amphibians, and a single species has been found to parasitize possums. Although they have a cosmopolitan distribution, a large proportion of taxa are exclusively found in South America. We analyzed the largest proteocephalidean cestode molecular dataset to date comprising more than 100 species (30 new), including representatives from 54 genera $(80 \%)$ and all subfamilies, thus significantly improving upon previous works to develop a molecular phylogeny for the group. The Old World origin of proteocephalideans is confirmed, with their more recent expansion in South America. The earliest diverging lineages are composed of Acanthotaeniinae and Gangesiinae but most of the presently recognized subfamilies (and genera) appear not to be monophyletic; a deep systematic reorganization of the order is thus needed and the present subfamilial system should be abandoned. The main characters on which the classical systematics of the group has been built, such as scolex morphology or relative position of genital organs in relation to the longitudinal musculature, are of limited value, as demonstrated by the very weak support for morphologically-defined subfamilies. How-
\end{abstract}

Copyright Alain de Chambrier et al. This is an open access article distributed under the terms of the Creative Commons Attribution License (CC BY 4.0), which permits unrestricted use, distribution, and reproduction in any medium, provided the original author and source are credited. 
ever, new characters, such as the pattern of uterus development, relative ovary size, and egg structure have been identified, which may be useful in defining phylogenetically well-supported subgroups. A strongly supported lineage infecting various snakes from a wide geographical distribution was found. Although several improvements over previous works regarding phylogenetic resolution and taxon coverage were achieved in this study, the major polytomy in our tree, composed largely of siluriform parasites from the Neotropics, remained unresolved and possibly reflects a rapid radiation. The genus Spasskyellina Freze, 1965 is resurrected for three species of Monticellia bearing spinitriches on the margins of their suckers.

\section{Keywords}

Eucestoda, Proteocephalidae, systematics, molecular phylogeny, host-parasite associations, Spasskyellina

\section{Introduction}

Proteocephalideans (Platyhelminthes: Cestoda) form a morphologically homogeneous group of tapeworms found worldwide in freshwater fishes, reptiles, and amphibians (a single species is known from marsupial mammals). To our knowledge 315 valid species are currently known (unpublished), a large proportion of them being parasites of South American siluriform fishes (Freze 1965, Rego 1994).

Proteocephalideans historically formed their own order (Proteocephalidea with only one family, Proteocephalidae), the monophyly of which is strongly supported, but recent molecular analyses have placed them within a paraphyletic assemblage of 'hooked' tetraphyllidean cestodes (formerly Onchobothriidae), parasites of sharks and rays, which has led to the erection of a new order, the Onchoproteocephalidea by Caira et al. (2014). However, the lack of any morphological synapomorphies for this new order made this a somewhat controversial decision. For the purpose of the present paper, which is to study the internal relationships of the "terrestrial" onchoproteocephalideans (= proteocephalideans), this point is marginal and the new scheme proposed by Caira et al. (2014) is not considered further.

Previous attempts to study the interrelationships of proteocephalideans resulted in overall poorly resolved phylogenies. At the morphological level, the difficulty of defining reliable informative characters has prevented the construction of a stable taxonomic arrangement of the group (Rego 1994, 1995). The traditionally accepted families Proteocephalidae and Monticelliidae have been abandoned, and the whole group has been split into a number of subfamilies and genera, including the type genus Proteocephalus Weinland, 1858, which are sometimes obviously artificial because of their lack of synapomorphies and diversity of life-history traits (see de Chambrier et al. 2004c, 2009a). Molecular studies that have tried to resolve the proteocephalidean tree topology have largely been based on the variable domains (D1-D3) of the large nuclear ribosomal RNA subunit (28S rDNA), using increasingly larger datasets, i.e. 54 taxa analyzed by Zehnder and Mariaux (1999), and 75 taxa by de Chambrier et al. (2004c). Hypša et al. (2005) analyzed the phylogenetic relationships of only 52 taxa, but used sequences of three ribosomal RNA genes and the internal transcribed spacer 2 (ITS2). Additional molecular studies mostly considered questions at the specific/generic level [e.g. the Proteocephalus aggregate (Scholz 
et al. 2007); African Proteocephalus (de Chambrier et al. 2011); Testudotaenia Freze, 1965 (de Chambrier et al. 2009a), Corallobothriinae (Rosas-Valdez et al. 2004, Scholz et al. 2011)] or employed only a very limited taxon sampling (e.g. Zehnder and de Chambrier 2000, Škeř́ková et al. 2001, de Chambrier et al. 2008, Scholz et al. 2013).

Although these studies have allowed for a better understanding of relationships within and between several subgroups, the major nodes of the proteocephalidean tree remain poorly supported, especially when considering the South American lineages. In the present contribution, an unprecedented collection of proteocephalidean samples have been gathered that includes the majority of all valid genera (54 out of 67), thus significantly increasing the taxon sampling within the order and adding representatives from previously unrepresented subfamilies. 28S rDNA sequences homologous to those published in studies by Zehnder and Mariaux (1999) and de Chambrier et al. (2004c) have been generated, and the newly generated data has been analyzed in conjunction with those previously published. Thus, the $28 \mathrm{~S}$ rDNA data presented here represent the most comprehensive sampling of proteocephalideans to date.

\section{Methods}

\section{Taxon sampling}

The present study is based on the evaluation of a dataset of proteocephalideans collected during long-term studies carried out by the present authors and their co-workers, especially as part of research activities linked to the NSF-PBI project "A Survey of the Tapeworms (Cestoda: Platyhelminthes) from Vertebrate Bowels of the Earth" (20082014), which was aimed at mapping the global diversity of tapeworms. Despite significant sampling effort covering all zoogeographical regions and the most important host groups, the number of studied proteocephalideans that parasitize amphibians remains relatively small due to the paucity of cestodes in these hosts. In addition, several newly described proteocephalideans from the southern part of the Neotropical Region (Argentina) were not available for molecular studies. Among the 13 proteocephalidean genera that are not represented in our sampling, none presently contains more than two species (see Caira et al. 2012).

All taxa considered in this study are listed in Table 1. Most taxa included in de Chambrier et al. (2004c) are included in the present analysis; however, some taxonomical changes and novel identifications have taken place since this paper was published: Proteocephalus pirarara (Woodland, 1935a) is now Scholzia emarginata (Diesing, 1850); Ophiotaenia cf. gallardi is now Ophiotaenia sp.; Pseudocrepidobothrium sp. is now Psendocrepidobothrium ludovici Ruedi \& de Chambrier, 2012; Megathylacus brooksi Rego \& Pavanelli, 1985 is now Megathylacus jandia (Woodland, 1934b); Spatulifer cf. maringaensis is now Spatulifer maringaensis Pavanelli \& Rego, 1989. All but five molecular samples are vouchered, and in $86 \%$ of cases the vouchers are the hologenophore (sensu Astrin et al. 2013). 


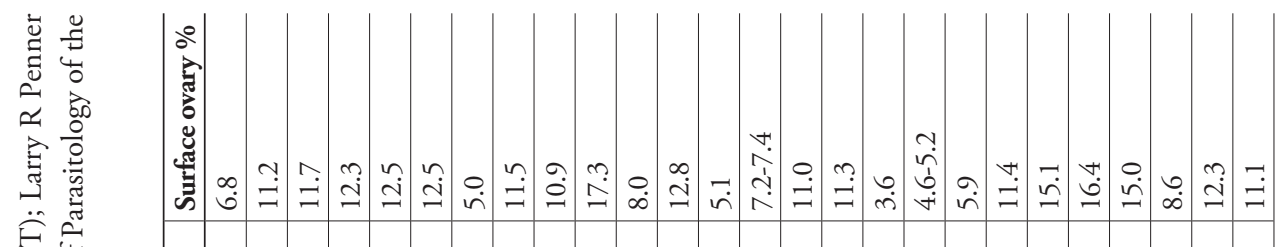

压峞

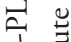

湜

$\sum \stackrel{1}{ \pm}$

站

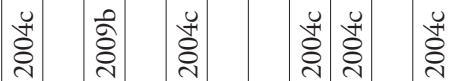

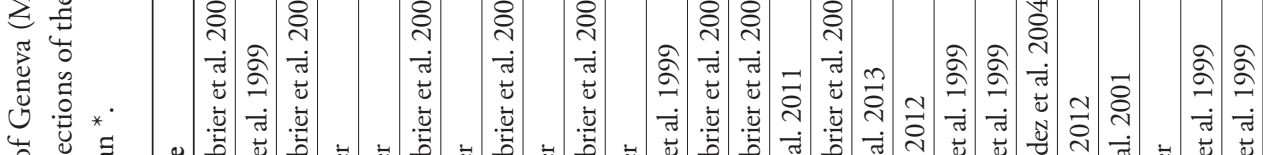

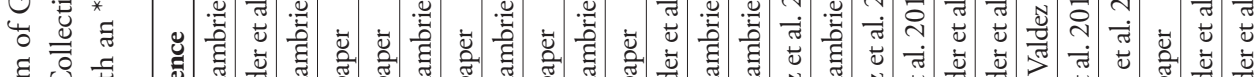

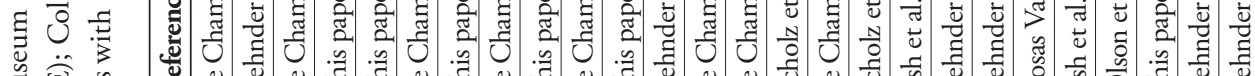
至空至

Z

至.

莺 离

艺 की

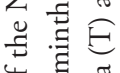

岸 吾

气

苛

离

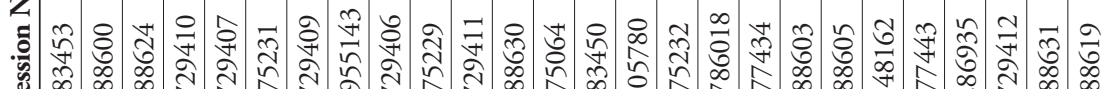

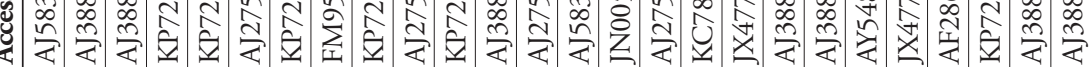

$\stackrel{\text { 乙 }}{\leftrightarrows}$

ค. ำ

岂苍

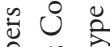

है

멸 胥

苛芯矛

$>$ ت

它芯

क

$\forall$ है

$\exists$ is

¿ :

$\Xi \approx$.

च्ठ

ซु

施

- 000

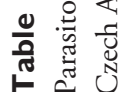

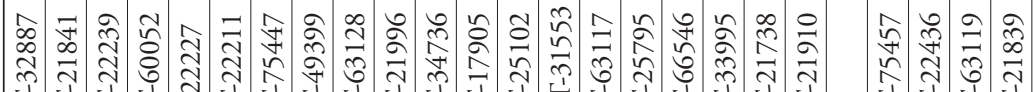

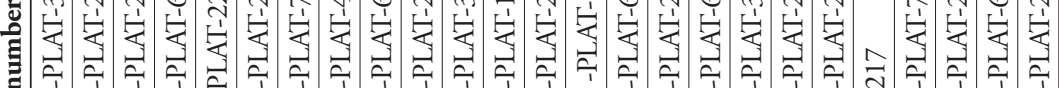

芴

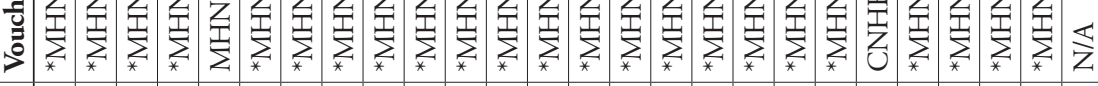
(2)

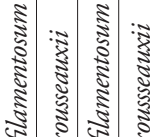

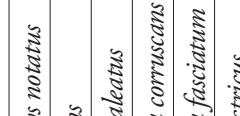

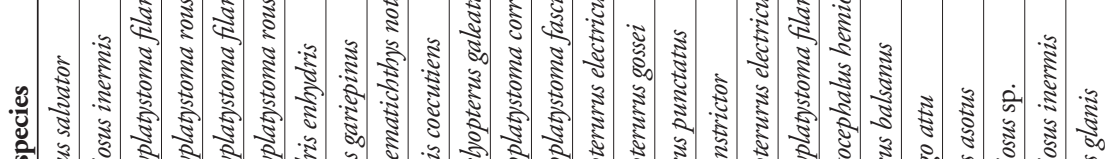

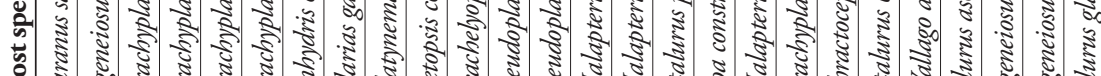

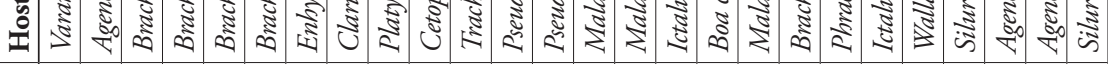




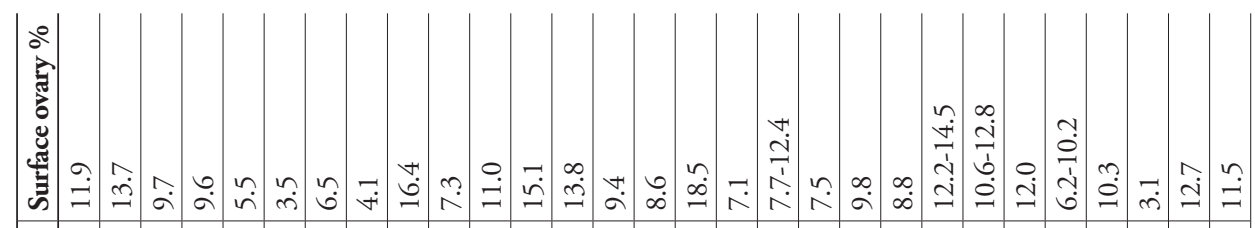

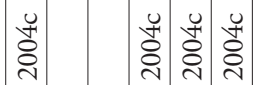

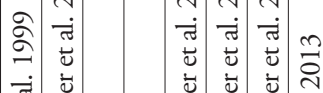

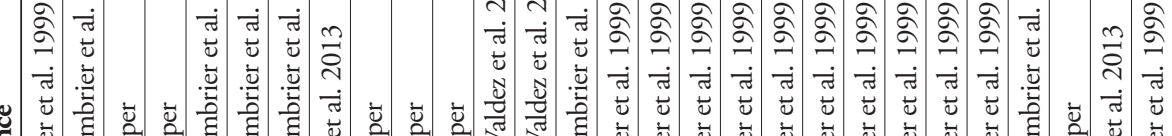

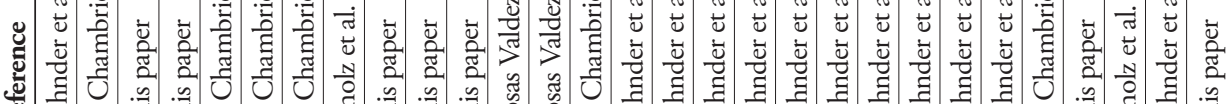
空

离

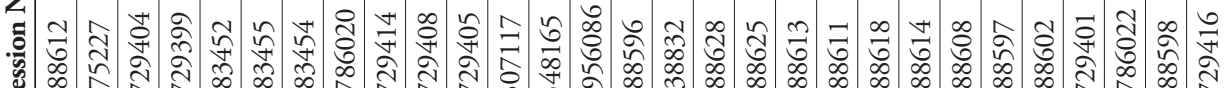

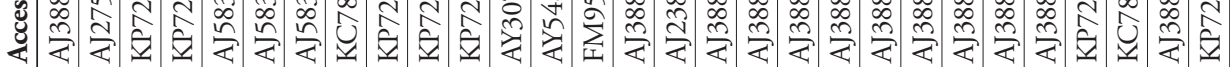

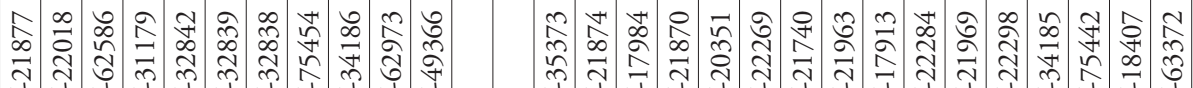

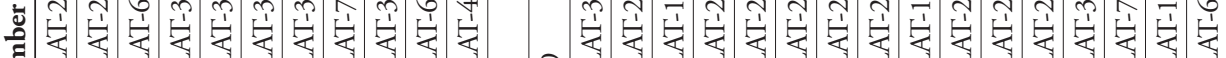

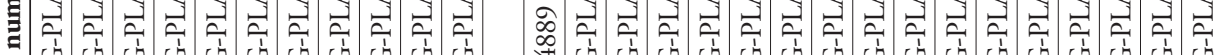

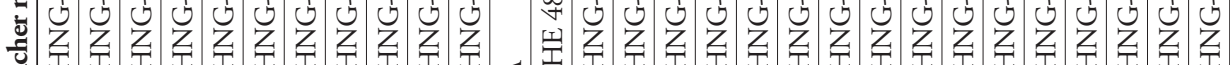

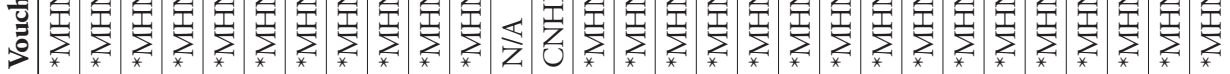

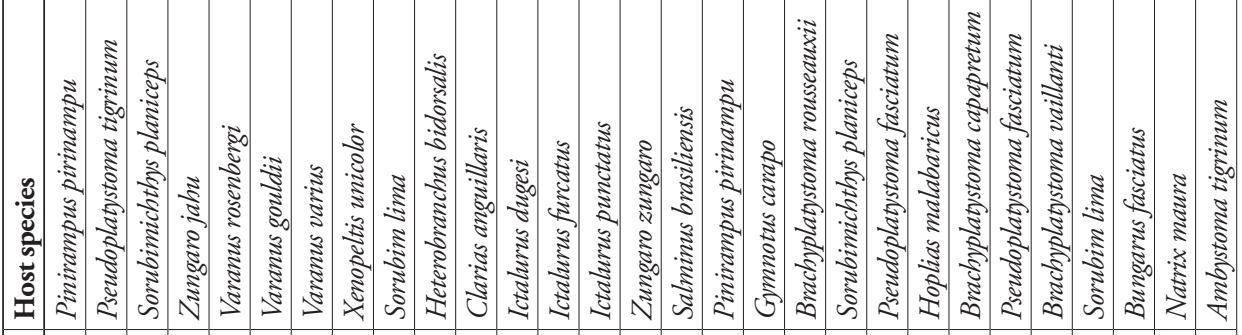

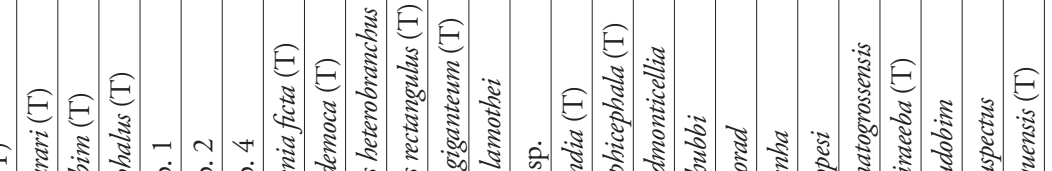

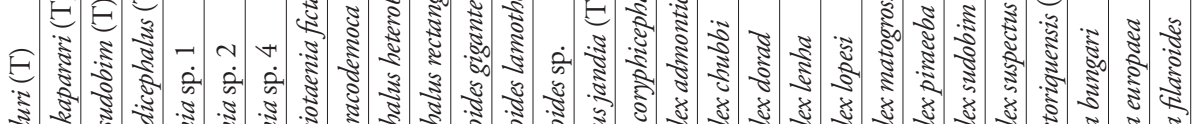

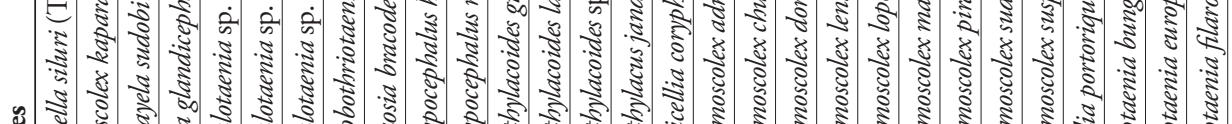

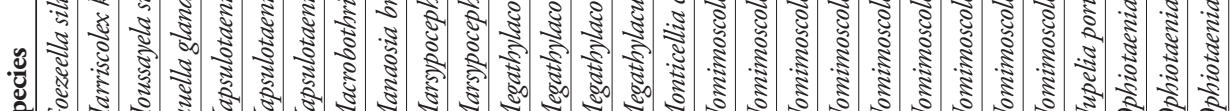
की 


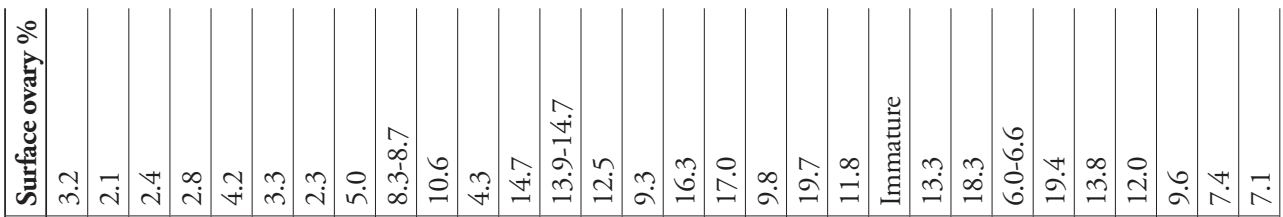

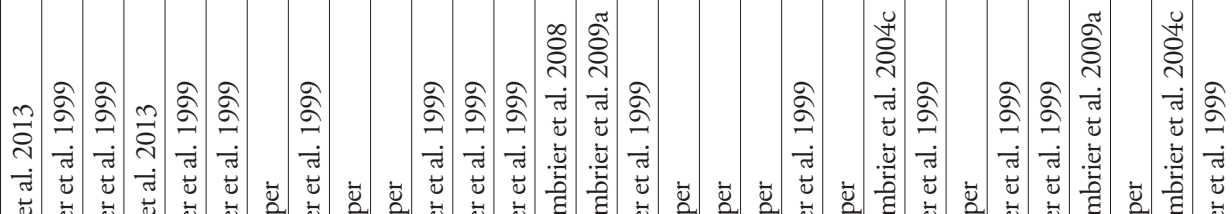

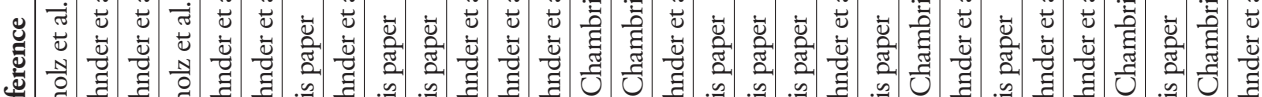

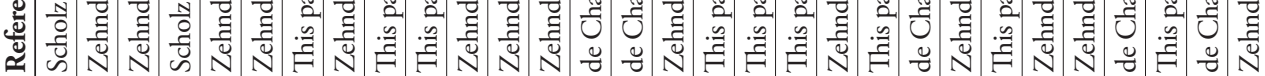

है

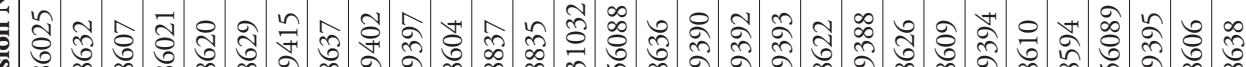

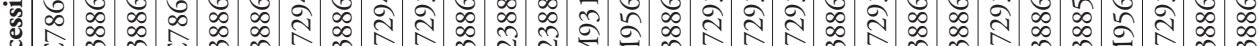

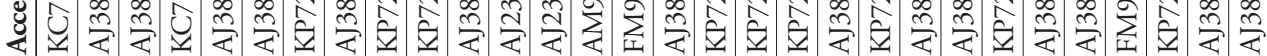

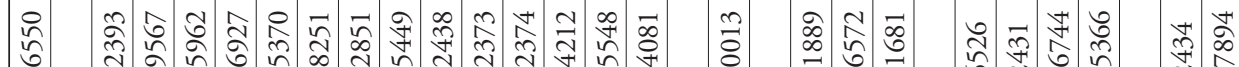

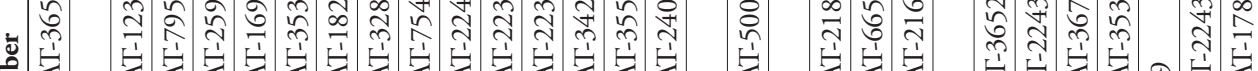

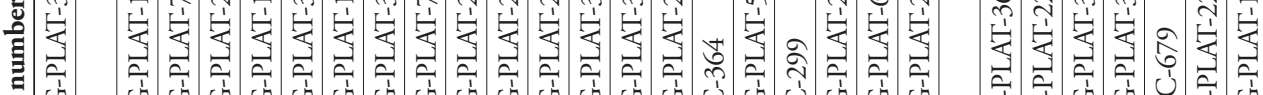
竎芜

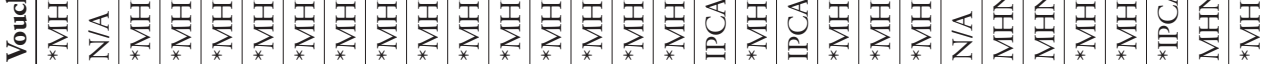

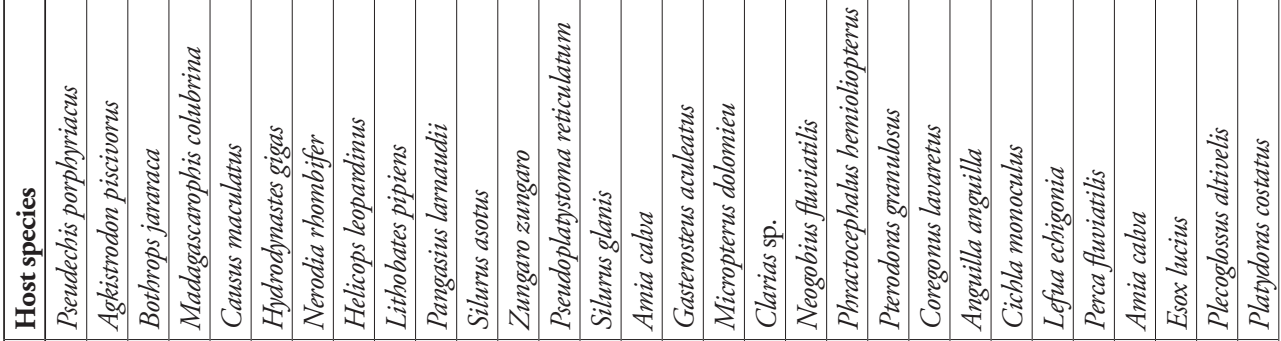

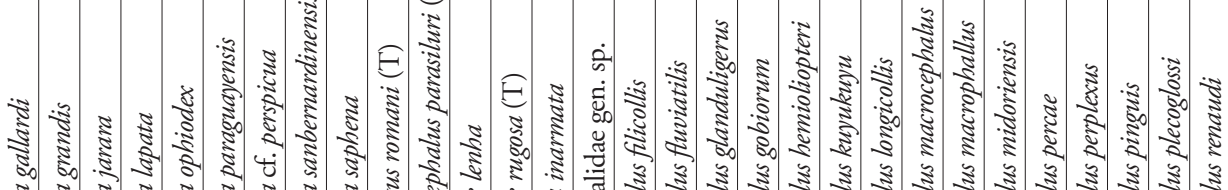

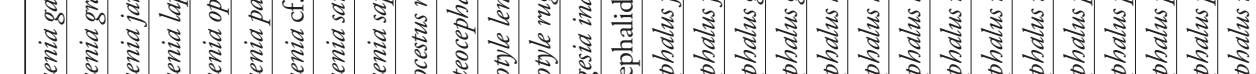




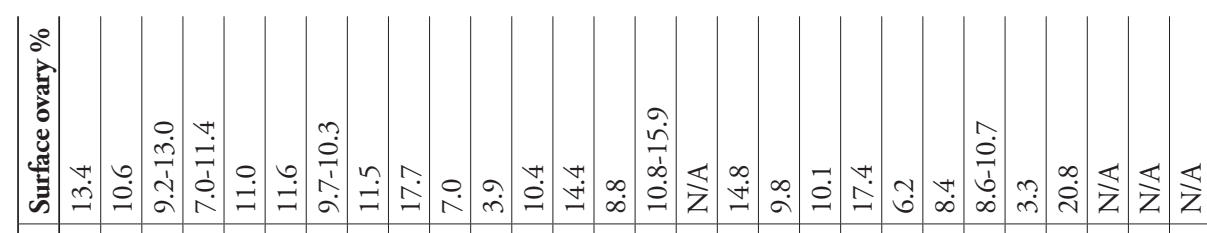

仓̊ำ

苍

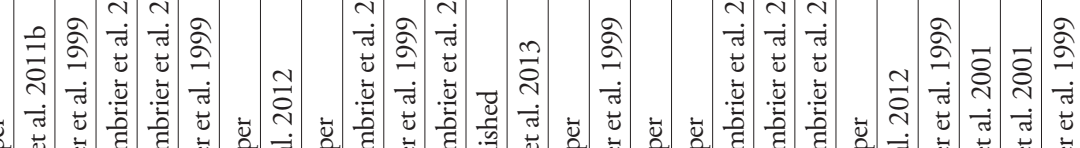

苍

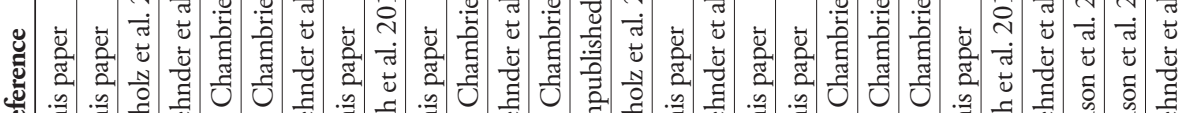
离

离

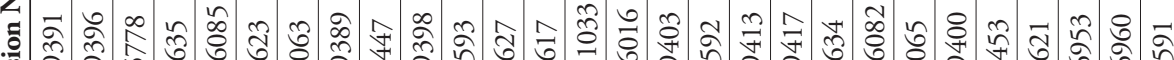

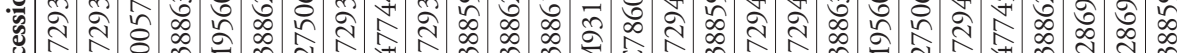

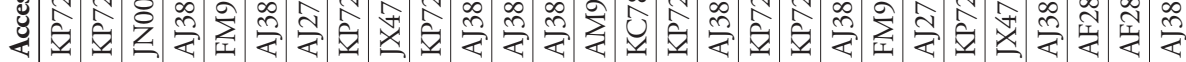

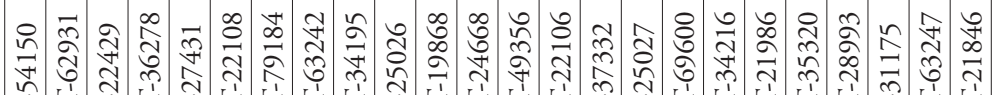

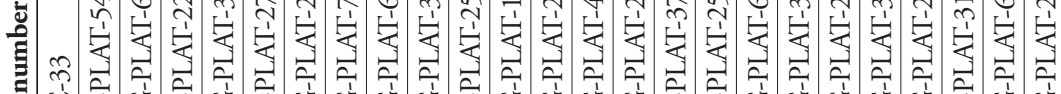

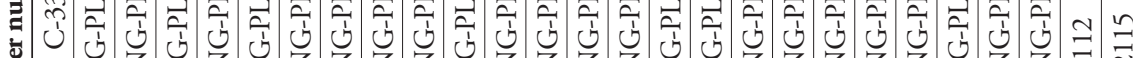
恶安

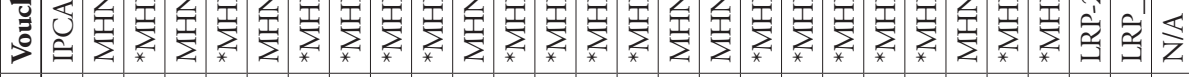

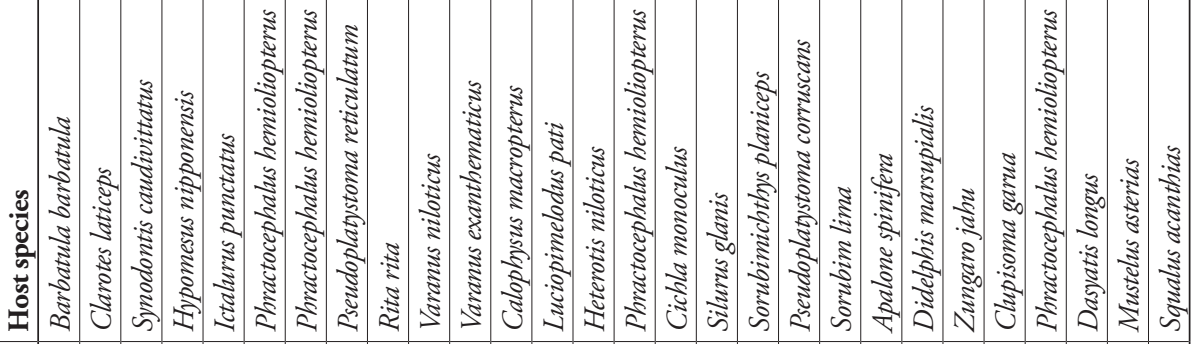

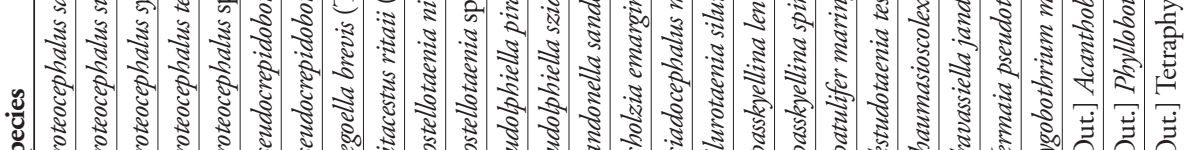

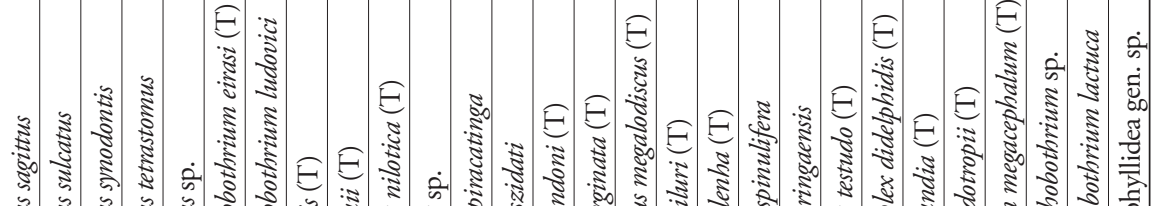

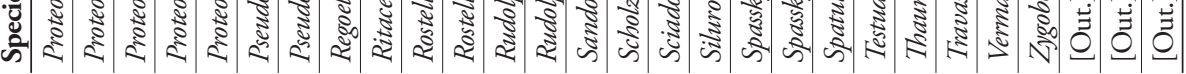




\section{Molecular phylogenetic analyses}

Total genomic DNA extraction, PCR amplification, and sequencing were done as outlined in Scholz et al. (2013). Eighty-three published and 30 newly generated $28 \mathrm{~S}$ rDNA sequences were combined and analysed in conjunction (see Table 1 for GenBank accession numbers and further details). Acanthobothrium sp. ('Onchoproteocephalidea'), Phyllobothrium lactuca Beneden, 1850 (Phyllobothriidea) and "Tetraphyllidea” gen. sp. were used as outgroup taxa. Sequences were aligned with MAFFT (Multiple Alignment using Fast Fourier Transform, http://www.ebi.ac.uk/Tools/msa/ mafft/) using the default settings. An alignment mask excluding sites of uncertain positional homology was generated using ZORRO (Wu et al. 2012). ZORRO uses a pair Hidden Markov Model and a weighted sum of pairs scheme (guided by a reference tree) that sums up the probability that a given alignment column appears over the total alignment landscape, thus providing an objective estimate of whether positions consist of correctly aligned, homologous residues. Default settings were used except for the invocation of the - sample option; positions with confidence scores $<0.4$ were excluded from subsequent analyses. MRMODELTEST v. 2.3 (Nylander 2004) was used to select models of sequence evolution using the Akaike Information Criterion. Bayesian inference (BI) analysis was performed using MRBAYES version 3.2 (Ronquist and Huelsenbeck 2003) using the GTR model of sequence evolution with proportion of invariant sites and gamma-distributed rate variation amongst sites $(\mathrm{nst}=6$, rates $=$ invgamma). Default prior settings and heating schemes were used. Two parallel runs were performed for 10,000,000 generations and sampled every 1,000 generations. The burn-in was defined as the point at which the average standard deviation of split frequencies were $<0.01$. Consensus trees were constructed using the $50 \%$ majority rule and nodes with $<0.95$ posterior probabilities (pp) were collapsed. Leaf-stability tests, implemented in P4 (Foster 2004), were carried out to identify unstable taxa. Given a set of trees, for each set of four taxa, the frequency of the four possible resolutions of quartets was calculated. For each taxon, the highest percentages for quartets including that taxon were averaged and listed as "Maximum". Therefore, unstable taxa across the trees were considered to be those that have lower average maximum percentages. In this study, the three taxa with the lowest "Maximum" values were eliminated from analyses in order to increase nodal support for the remaining groupings (Wilkinson 1996).

\section{Morphological analysis}

Taxonomic identification was performed on specimens fixed and mounted on microscope slides according to de Chambrier (2001). Uterine development was characterized according to de Chambrier et al. (2004c) but a new "intermediate type" was recognized and is described below (see Fig. 2). The relative size of the ovary, i.e. the ovary to proglottid surface ratio, was calculated for each species according to the 
method described in de Chambrier et al. (2012). Approximate values might be due to inaccurate drawings or fixation methods reported by the original authors. Eggs were examined in distilled water.

\section{Data Resources}

The data underpinning the analysis reported in this paper are deposited in the Dryad Data Repository at http://dx.doi.org/10.5061/dryad.dv44b.

\section{Results}

\section{Molecular phylogeny}

The complete $28 \mathrm{~S}$ rDNA dataset comprised 110 ingroup taxa (from 54 genera, representing all 13 currently recognized subfamilies) and three outgroup taxa. Importantly, 46 genera were represented by their type species (see Table 1). The alignment consisted of 1937 characters of which 420 were excluded, leaving 1517 for the analyses.

In an initial BI analysis, several nodes had posterior probabilities $(\mathrm{pp})<0.95$, resulting in a tree with only 60 well-supported nodes (see Suppl. material 1: Fig.1). In order to identify unstable taxa for subsequent exclusion, a leaf stability test was conducted. This revealed Vermaia pseudotropii (Verma, 1928), Sciadocephalus megalodiscus Diesing, 1850 and Manaosia bracodemoca Woodland, 1935 to be the least stable taxa (see Suppl. material 2: Table 1). Curiously, the position of the longest branching taxon, Sandonella sandoni (Lynsdale, 1960), was very stable (Fig. 1b inset; Suppl. material 1: Fig.1, Suppl. material 2: Table 1). The positions of the excluded taxa were as follows: Vermaia pseudotropii was in an unresolved position at the base of the tree, Sciadocephalus megalodiscus was in an unresolved position in a clade composed of the ingroup taxa to the exclusion of Gangesiinae Mola, 1929 and Acanthotaeniinae Freze, 1963, and Manaosia bracodemoca was in an unresolved position in the large subclade of Clade D (Suppl. material 1: Fig.1).

In a subsequent BI analysis, in which the above-mentioned three taxa had been excluded, three nodes had improved support ( $\geq 0.95 \mathrm{pp})$, resulting in 63 well-supported nodes in total (Fig. 1a, b). Thus, further topology descriptions are based on the better-supported tree in which nodes of particular interests were labeled Clades $A-P$ (Fig. 1a, b). Specifically, those better-supported nodes concern the positions of (i) Postgangesia inarmata de Chambrier, Al-Kallak \& Mariaux, 2003, (ii) Ritacestus ritaii (Verma, 1926), and (iii) the sister-group relationship between Choanoscolex sp. and Nomimoscolex sudobim Woodland, 1935 (Fig. 1a, b; Suppl. material 1: Fig.1). Thus, the Gangesiinae were shown to be non-monophyletic except for a clade composed of Electrotaenia malopteruri (Fritsch, 1886), Silurotaenia siluri (Batsch, 1786) and Gangesia spp. (Fig. 1a). 
$1 \mathrm{a}$

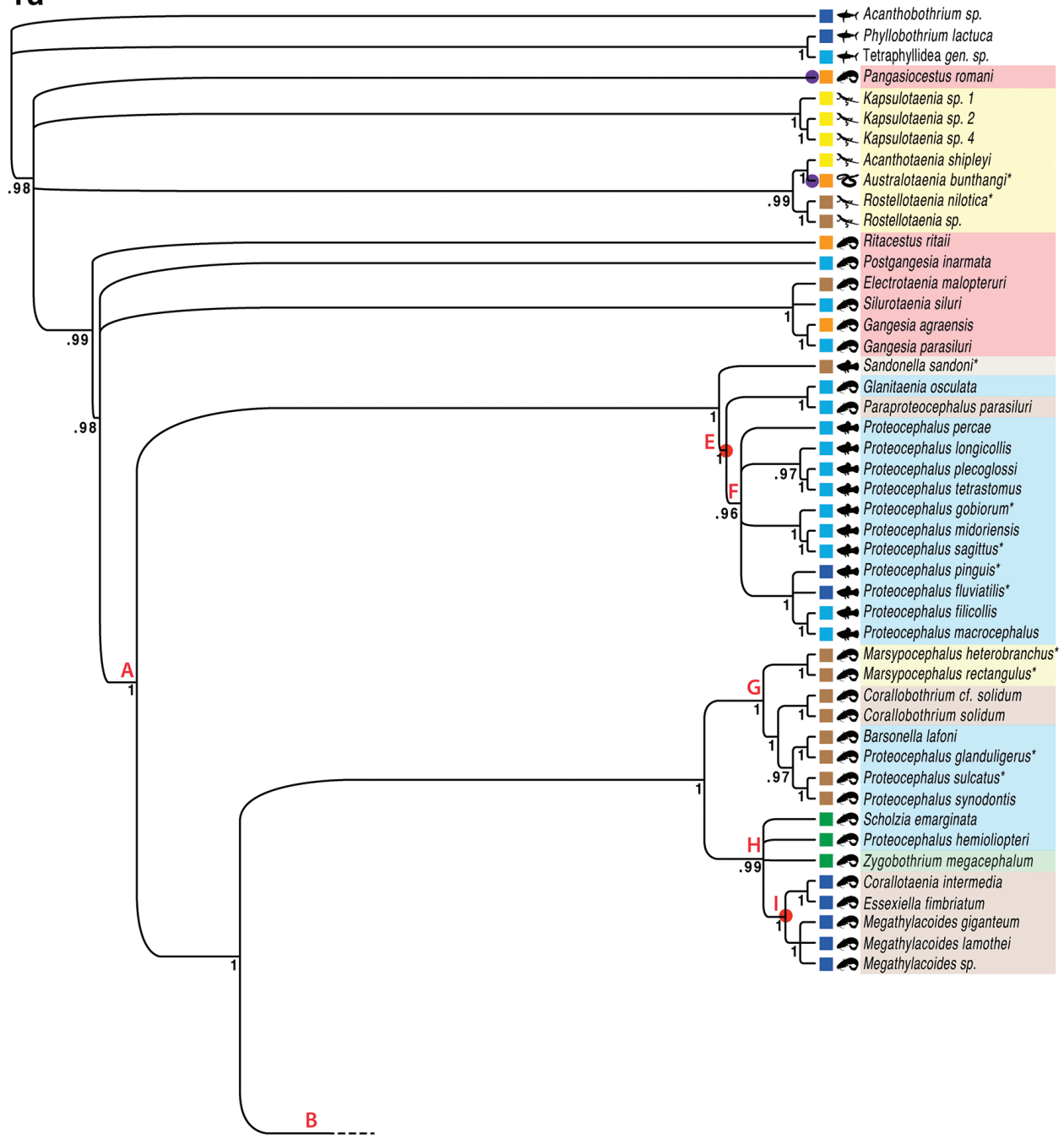

\begin{tabular}{|c|c|c|c|}
\hline Acanthotaeniinae & Peltidocotylinae & - elasmobranchs & Afrotropic \\
\hline Corallobothriinae & Proteocephalinae & catfishes & Australasia \\
\hline Ephedrocephalinae & Rudolphiellinae & non siluriform fishes & Indomalaya \\
\hline Gangesiinae & Sandonellinae & * lizards & Palearctic \\
\hline Marsypocephalinae & Testudotaeniinae & 5 snakes & Neotropic \\
\hline Monticelliinae & Zygobothriinae & turtles & \\
\hline Nupeliinae & & & \\
\hline
\end{tabular}

Figure I. Bayesian inference of partial (domains 1-3) $28 \mathrm{~S}$ rDNA sequences of a reduced taxon set of proteocephalideans (unstable taxa Sciadocephalus megalodiscus, Vermaia pseudotropii and Manaosia bracodemoca have been removed) performed using MrBayes version 3.2 using the GTR + I + G model of sequence evolution. Two parallel runs were performed for 10,000,000 generations; 4,000,000 generations were discarded as burnin. Branches with posterior probability (pp) support below $95 \%$ are collapsed; pp 


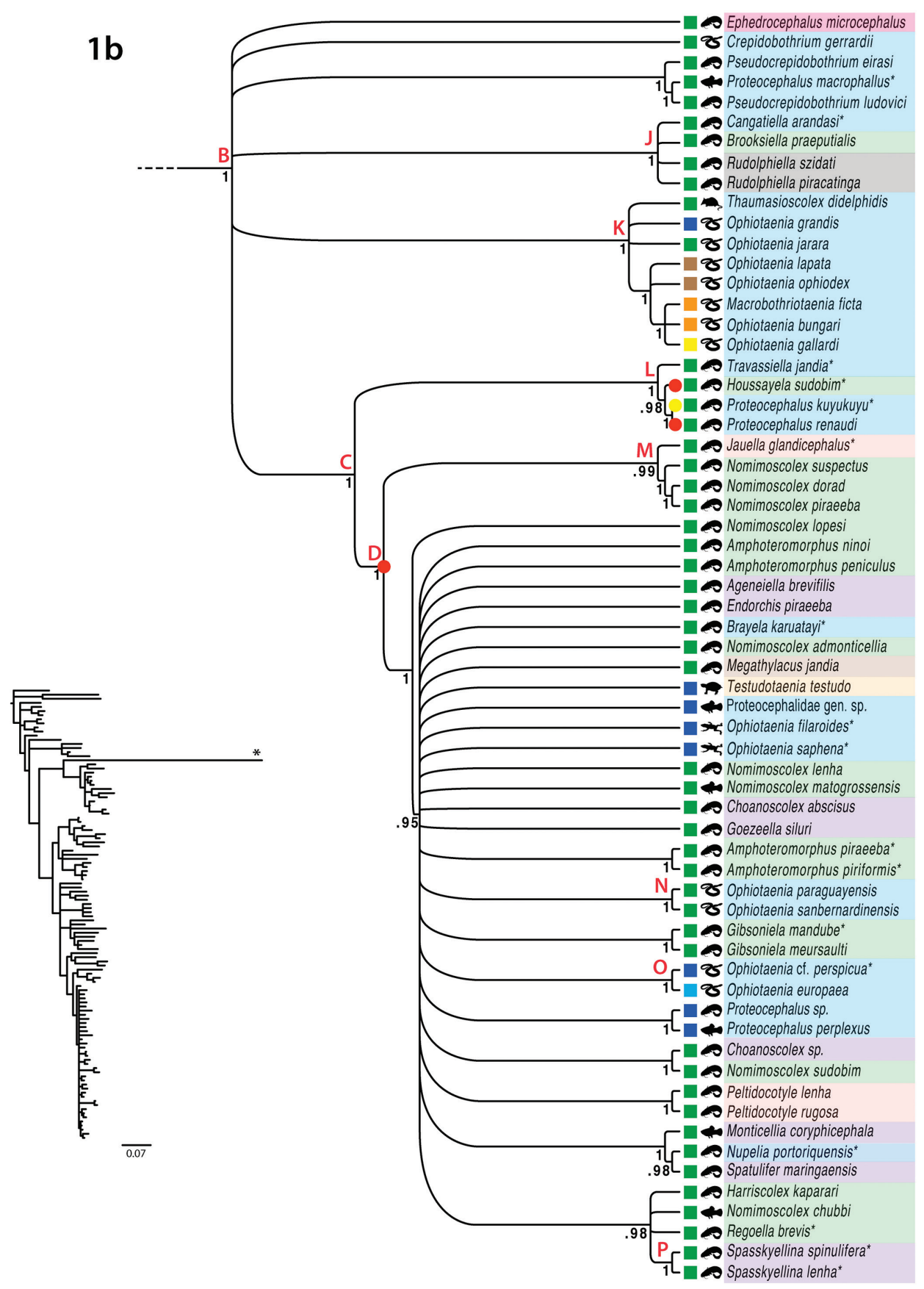

are indicated below branches. Asterisks mark new sequences. Red letters A to P refer to specific nodes discussed in the text. Red circles refer to the acquisition of "Type 2" uterus development; purple circles: acquisition of "intermediate type" uterus development; yellow circle: uterus development unknown (see Discussion). A mute phylogram of the same tree is inserted and the long branch leading to Sandonella sandoni is marked with an asterisk. 
The three earliest diverging lineages were formed of Pangasiocestus romani Scholz $\&$ de Chambrier, 2012 and the Acanthotaeniinae, where the Acanthotaeniinae were possibly non-monophyletic, split into a monophyletic Kapsulotaenia Freze, 1965, and a monophyletic assemblage of Acanthotaenia shipleyi + Australotaenia bunthangi + Rostellotaenia spp. (posterior probability $=0.88$; not shown), but where all three lineages took an unresolved position at the base of the tree.

The Gangesiinae formed three paraphyletic lineages composed of Ritacestus ritaii, Postgangesia inarmata, and a clade composed of Electrotaenia malopteruri, Silurotaenia siluri and Gangesia spp. (Fig. 1a), to the exclusion of the remainder of the tree (Clade A).

The remainder of the tree (Clade $A$ ) was structured as follows: The earliest diverging group consisted of Sandonella sandoni (Lynsdale, 1960) which parasitizes an ancient osteoglossiform fish in Africa and which formed the sister group to Clade E. The latter was composed of two monotypic sister taxa Glanitaenia de Chambrier, Zehnder, Vaucher \& Mariaux, 2004 (Proteocephalinae) and Paraproteocephalus Chen in Dubinina, 1962 (Corallobothriinae), both of which parasitize silurid catfishes in the Palearctic Region. These, in turn, formed the sister group to Clade F, which was composed of the Proteocephalus aggregate (see de Chambrier et al. 2004c) from Holarctic teleosts, including two newly added species from North America, P. fluviatilis Bangham, 1925 and P. pinguis La Rue, 1911.

The next well-supported group structured of Clade $G$, which was exclusively composed of taxa from African siluriforms belonging to three subfamilies (Corallobothriinae, Marsypocephalinae and Proteocephalinae), and which formed the sister group to Clade H. The latter was composed of Scholzia emarginata, Proteocephalus hemioliopteri de Chambrier \& Vaucher, 1997 and Zygobothrium megacephalum Diesing, 1850, all of which are anatomically similar parasites of the Neotropical catfish Phractocephalus hemioliopterus (Bloch \& Schneider, 1801), but which are traditionally placed in different subfamilies, and of a monophyletic group of Nearctic proteocephalideans (Clade I), all parasitizing channel catfish (Ictaluridae); members of Clade I are placed in the Corallobothriinae because they possess a metascolex.

The most derived assemblage, Clade B, remained largely unresolved, with five early diverging lineages composed of (i) Ephedrocephalus microcephalus Diesing, 1850, (ii) Crepidobothrium gerrardii Monticelli, 1900, (iii) a clade of Pseudocrepidobothrium spp. + Proteocephalus macrophallus (Diesing, 1850), (iv) Clade J, composed of Rudolphiella spp. + Cangatiella arandasi Pavanelli \& Machado dos Santos, 1991 + Brooksiella praeputialis (Rego, Santos \& Silva, 1974), and (v) Clade K, composed of Ophiotaenia spp., Macrobothriotaenia ficta (Meggitt, 1931), all parasites of snakes from various zoogeographical regions, and Thaumasioscolex didelphidis Cañeda-Guzmán, de Chambrier \& Scholz, 2001, the only proteocephalidean found in possums; (i)-(iv) were exclusively from the Neotropics.

The large polytomy found in Clade $C$ was, to a large degree, composed of proteocephalideans parasitizing South American fishes (predominantly siluriforms of the families Pimelodidae, Auchenopteridae and Doradidae). Clade L formed the earliest diverging lineage of Clade $C$ and was composed of Travassiella jandia (Woodland, 1934), Houssayela sudobim (Woodland, 1935) and Proteocephalus kuyukuyu Wood- 
land, 1935 and $P$. renaudi de Chambrier \& Vaucher, 1994. The sister group to the large polytomy in Clade $C$ was formed of Clade $M$, which included Jauella glandicephalus Rego \& Pavanelli, 1985, Nomimoscolex suspectus Zehnder, de Chambrier, Vaucher \& Mariaux, 2000, N. dorad (Woodland, 1935) and N. piraeeba Woodland, 1934. The remainder of Clade $C$ formed largely a comb which comprised, amongst others, Testudotaenia testudo (Magath, 1924), a parasite of North American soft-shelled turtles and bowfin (Amia calva), a clade of Proteocephalus sp. and Proteocephalus perlexus La Rue, 1911, parasitizing North American catfish and bowfins respectively, two distinct clades of Ophiotaenia La Rue, 1911, Clade N (parasites of South American snakes) and Clade $O$ (parasites of European and Nearctic snakes), and two unresolved Ophiotaenia species, O. filaroides La Rue, 1909 and O. saphena Osler, 1931, parasitizing North American salamanders and frogs, respectively.

The possible monophyly of 17 proteocephalidean genera could be examined, at least preliminarily, because two or more species of these genera were included in our analyses (numerous proteocephalidean genera are monotypic or species-poor). According to the current taxon sampling, the following genera, listed alphabetically, appeared monophyletic (the numbers in parentheses indicate the total number of species sequenced and the number of distinct lineages in which species of a given genus appeared): Corallobothrium Fritsch, 1886 (2/1), Gangesia Woodland, 1924 (2/1), Gibsoniela Rego, 1984 (2/1), Kapsulotaenia Freze, 1965 (3/1), Marsypocephalus Wedl, 1861 (2/1), Megathylacoides Jones, Kerley \& Sneed, 1956 (3/1), Peltidocotyle Diesing, 1850 (2/1), Proteocephalus aggregate (11/1), Rostellotaenia Freze, 1963 (2/1) and Spasskyellina Freze, 1965 (2/1) (see discussion below for the latter). The monophyly of Rudolphiella Fuhrmann, 1916 (2/1) was not rejected by these results. In contrast, Pseudocrepidobothrium Rego \& Ivanov, 2001 (2/2) is paraphyletic and the genera Amphoteromorphus Diesing, 1850 (4/3), Choanoscolex La Rue, 1911 (2/2), Nomimoscolex Woodland, 1934 (9/7), Ophiotaenia (12/10) and Proteocephalus (20/7) appeared to be polyphyletic based on their current classification.

\section{Morphological analysis}

At the morphological level, the ovary to proglottid surface ratio ranged between $2.0 \%$ in Ophiotaenia grandis La Rue, 1911 to 20.8\% in Zygobothrium megacephalum (Table 1). Examination of new whole mounts also identified a novel form of the uterine development in addition to those described by de Chambrier et al. (2004c). This development is characterized as follows: in immature proglottids, the uterine stem forms an elongated concentration of chromophilic cells; in premature proglottids the chromophilic cells concentrate in areas where lateral uterine extensions will develop; in mature proglottids, a tubular uterine stem appears and develops small thin-walled lateral diverticula topped with a conspicuous concentration of numerous intensely stained cells; in pregravid and gravid proglottids, the lateral diverticula grow and eventually occupy most of the proglottid width (Fig. 2b, d). We call this development "intermediate type". 

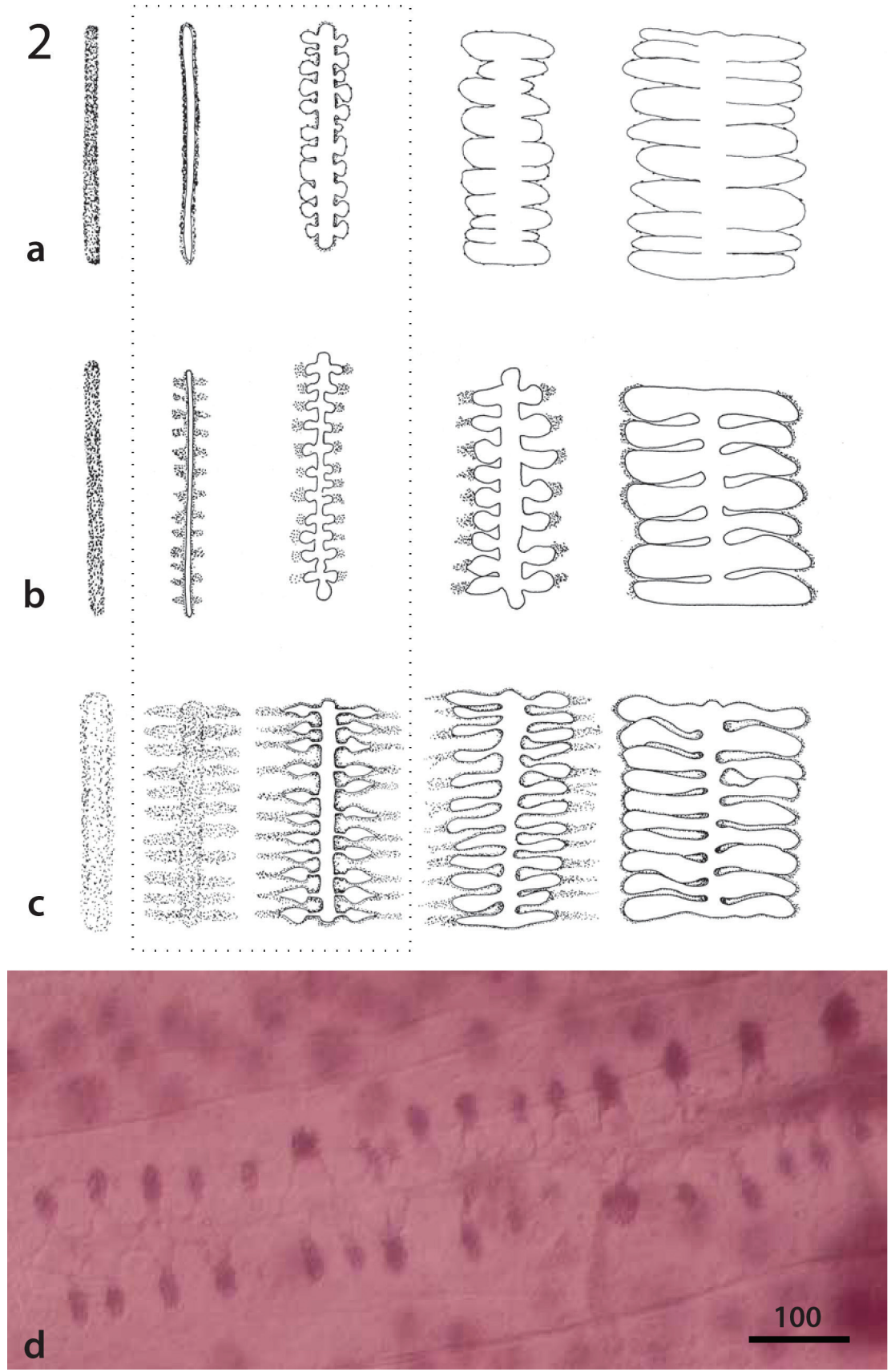

Figure 2. Schematic representation of proteocephalidean uterus development $(\mathbf{a}-\mathbf{c})$. The uterus observed in early immature, premature, mature, pregravid and gravid proglottids is represented from left to right. The major differences are observed in premature and mature proglottids (dotted line): $\mathbf{a}$ and $\mathbf{c}$ Development of Type 1 and 2, respectively (de Chambrier et al. 2004c) b Development of an "intermediate type" as observed in Pangasiocestus and Australotaenia (this paper) d Typical "intermediate type" uterus in a mature proglottid of Australotaenia bunthangi de Chambrier \& Scholz, 2012 (holotype, MHNGPLAT-75447). Scale in micrometers. 


\section{Discussion}

Since the publications of de Chambrier et al. (2004c) and Hypša et al. (2005), no attempt has been made to unravel the phylogenetic structure of proteocephalideans. Two immediate observations can be made when comparing our results to the de Chambrier et al. (2004c) tree: (1) an overall better resolution is achieved with the increased taxon sampling; and (2) all clades that were supported in de Chambrier et al. (2004c) remain so in these results. However, a number of differences can also be noted as discussed below.

\section{Early diverging lineages - Acanthotaeniinae and Gangesiinae}

In both de Chambrier et al. (2004c) and the present study, the Gangesiinae from Siluriformes, mostly in Indomalaya and Palearctic (but with one species in Afrotropics), and Acanthotaeniinae from reptiles in Australasia, Afrotropic and Indomalaya are early diverging lineages. However, their order is now reversed with the Acanthotaeniinae, together with Pangasiocestus romani (Gangesiinae), taking the earliest diverging position. Thus, the present results suggest either the paraphyly of the subfamily or the necessity to handle Pangasiocestus Scholz \& de Chambrier, 2012 as an independent lineage. This monotypic genus was initially placed in the Gangesiinae based on its scolex morphology, which is characterized by a large rostellum-like apical organ. However, it differs from all gangesiine in a number of morphological characteristics. These include the peculiar, rosette-like scolex with a large, discoidal apical organ devoid of hooks; a very weakly-developed inner longitudinal musculature, which does not form bundles (unlike those of other gangesiine genera, which form numerous bundles of muscle fibers; see Scholz et al. 1999, de Chambrier et al. 2003, de Chambrier et al. 2004b, Ash et al. 2012 for more details); and the variable size of testes, which are considerably smaller and denser in the lateral than in the median field. These morphological features support the separation of Pangasiocestus from the Gangesiinae, as shown by our genetic analysis, despite the superficial resemblance of its scolex with that of other gangesiine cestodes.

It should also be noted that, together with Australotaenia de Chambrier \& de Chambrier, 2010, Pangasiocestus has a particular, intermediate development of the uterus (see below), that contrasts that of all other Gangesiinae and Acanthotaeniinae, which have a Type 1 development of the uterus. P. romani was found in a catfish in Cambodia, and species of Australotaenia are distributed in Australia and Indomalaya, which would suggest an Old World origin for proteocephalideans. This scenario is consistent with the results of de Chambrier et al. (2004c) and contradicts the hypothesis of Brooks (1978), who favored a South American origin of the group.

\section{The Proteocephalus aggregate and the enigmatic Sandonella and Sciadocephalus}

The position of Sandonella Khalil, 1960 as a separate long-branching lineage, as already observed by de Chambrier et al. (2008), was confirmed in the present study. Sandonella 
formed the sister group to the strongly supported Clade E, which is composed of species of the Proteocephalus aggregate (Clade F) that are parasites of teleosts in the Holarctic Region, and monotypic genera Glanitaenia and Paraproteocephalus, which are parasites of silurid catfish in the Palearctic Region. The members of the Proteocephalus aggregate (= Proteocephalus sensu stricto) will retain the generic name since this clade undoubtedly includes $P$. ambiguus (Dujardin, 1845), the type species of Proteocephalus, as shown by Scholz et al. (2007). The addition of two Proteocephalus species of Nearctic origin [P. fluviatilis from centrarchids (Perciformes) and P. pinguis from pikes (Esociformes)] to the dataset revealed their affinity with the Proteocephalus aggregate. This close phylogenetic relationship of the Palearctic and Nearctic taxa analyzed is in accordance with their similar morphology (Freze 1965, Scholz and Hanzelová 1998). The diversity of hosts in Clade $E$ is surprising when compared to other subgroups of proteocephalideans that generally diversify in discrete groups of catfish. In this case a Holactic radiation of these cestodes in multiple groups of fishes has occurred.

Sandonella sandoni was placed in a new genus and subfamily, Sandonellinae, mostly because of the characteristic posterior position of its vitellarium, which is unique among proteocephalideans and somewhat resembles that of the Cyclophyllidea in being formed by two compact, yet deeply lobulated postovarian masses near the posterior margin of the proglottids (Khalil 1960, see also fig. 6 in de Chambrier et al. 2008). Bâ and Marchand (1994) observed the unique structure of $S$. sandoni spermatozoa (with a single axoneme) and de Chambrier et al. (2008) reported its widespread presence in Heterotis niloticus (Cuvier, 1829) throughout Africa and described additional original morphological characters such as a scolex with a highly modified apical structure formed by 4 muscular retractile lappets, a dilated, vesicle-like proximal part of the external sperm duct, a unique morphology of the uterus, and a complex proglottization with mixed smaller and larger (wider) proglottids. Despite these peculiarities, as well as its derived $28 \mathrm{~S}$ sequence, the position of $S$. sandoni as a sister group of Holarctic Proteocephalinae was established by de Chambrier et al. (2008) and is not questioned by these results. The presence of this relatively derived parasite in a basal fish lineage (Osteoglossiformes) is further evidence that the evolution of proteocephalideans does not closely match that of their hosts. It should be noted though that the phylogenetic position of this taxon has not yet been tested in more global cestode phylogenies (i.e. Waeschenbach et al. 2012, Caira et al. 2014).

Sciadocephalus megalodiscus parasitizing Cichla monoculus Agassiz, 1831 (Perciformes) in the Neotropical region and described by Diesing (1850) is another enigmatic taxon. In its redescription Rego et al. (1999) noted several peculiar morphological features, such as an umbrella-shaped metascolex, a uterus rapidly resolving into capsules, and a musculature with numerous isolated longitudinal fibers, and placed the species in the Corallobothriinae based on the presence of a metascolex [which is, however, a homoplastic character (Scholz et al. 2013)] and the medullary position of the genital organs. In our initial evaluation, this taxon appeared as the earliest diverging lineage of Clade A (see Suppl. material 1: Fig.1) but it has also been identified as one of the three least stable taxa in the analysis and had therefore been excluded from fur- 
ther analyses. Nevertheless, this possible distinct position of the species among proteocephalideans, supported by its combination of peculiar morphological characteristics, might justify its future placement in a separate, higher taxonomic group.

\section{African fish proteocephalideans}

Our considerably enlarged dataset of fish proteocephalideans from Africa covers most of their diversity and includes all genera reported from the Afrotropical Region. It revealed that all but one species (the gangesiine Electrotaenia malopteruri - see above) from African siluriform fish form a well-supported, relatively basal Clade G. This is one of the most important novelties of the present study: species placed in three subfamilies are phylogenetically closely related despite important morphological differences. These are: i) the Corallobothriinae (two species of Corallobothrium including its type species from malapterurid electric catfish) characterized mainly by a well-developed metascolex and medullary testes; ii) the Marsypocephalinae (tow species from clariids) with a simple scolex and cortical testes; and iii) the Proteocephalinae (three Proteocephalus species from clariid, claroteid and mochokid catfish, and Barsonella lafoni de Chambrier, Scholz, Beletew \& Mariaux, 2009 from Clarias spp.), with a relatively simple scolex and medullary testes (de Chambrier et al. 2009b). This grouping of taxa with markedly different scoleces as well as conspicuously distinct position of the testes (medullary versus cortical) is further evidence that morphological characteristics related to the scolex and internal topology of genital organs are homoplastic and should be interpreted with great caution. A similar situation was demonstrated in Macrobothriotaenia ficta, a snake parasite from Indomalaya, which possesses a tetraphyllidean-like scolex: it is closely related to species of Ophiotaenia with a simple scolex (Scholz et al. 2013; see also Clade K), but less so with Thaumasioscolex didephidis despite having a very similar scolex morphology. The new results also indicate that zoogeography and host associations may have played a much more important role in the evolutionary history of proteocephalidean cestodes than previously thought (Freze 1965, Rego et al. 1998).

\section{Parasites of the Neotropical pimelodid catfish Phractocephalus hemioliopterus}

Neotropical catfish, in particular pimelodids, harbour the highest number of species (and genera) of proteocephalidean cestodes. However, these parasites do not form a monophyletic assemblage, even though most of them belong to our most derived clade with unresolved internal relationships (see also Zehnder and Mariaux 1999, de Chambrier et al. 2004c). The current study confirmed the polyphyly of these cestodes, including the markedly distant position of three species from the pimelodid catfish Phractocephalus hemioliopterus (Clade H) from the remaining cestodes parasitizing other siluriforms from South America, as first observed in a much smaller dataset by Hypša et al. (2005). 
As many as six species reported from $P$. hemioliopterus were included in our analyses. Three of them, namely Proteocephalus hemioliopteri, Scholzia emarginata (both Proteocephalinae) and Zygobothrium megacephalum (Zygobothriinae), differ markedly from each other in their scolex morphology (see de Chambrier et al. 2005), yet form a well-supported lineage (Clade H) together with Nearctic "corallobothriines" (Clade I). Their phylogenetic position is, thus, more basal and distant from that of other proteocephalideans parasitizing Neotropical teleosts.

The remaining three taxa that parasitize $P$. hemioliopterus, i.e. two species of Pseudocrepidobothrium (Proteocephalinae) and Ephedrocephalus microcephalus Diesing, 1850 (Ephedrocephalinae) group in an unresolved position towards the base of the South American radiation. This suggests possible independent colonizations of this host. The basal position of these parasites is in accordance with the fact that $P$. hemioliopterus is one of the most ancient pimelodids, as suggested by fossil records dating from Middle to Late Miocene (Lundberg and Littmann 2003).

Our data do not enable any reliable assessment regarding a possible host-parasite coevolution, especially in the case of pimelodid catfishes and their Neotropical proteocephalideans. A comparison of the interrelationships of the Pimelodidae based on robust morphological and molecular evidence (Lundberg et al. 2011 and references therein) with the present data does not reveal any obvious pattern of possible coevolutionary history. In fact, cestodes from closely related pimelodids such as species of Pseudoplatystoma Bleeker, 1862 and Sorubimichthys planiceps (Spix \& Agassiz, 1829) are unrelated and belong to distant lineages (Table 1 and Fig. 1a, b).

\section{Nearctic "corallobothriines" from channel catfishes (Ictaluridae)}

Nearctic species from channel catfish form a well-supported, monophyletic lineage (Clade I) composed of species of three genera, Essexiella Scholz, de Chambrier, Mariaux \& Kuchta, 2011, Megathylacoides and Corallotaenia Freze, 1965. However, the Nearctic genera, conventionally placed in the Corallobothriinae because they possess a metascolex, are not closely related to the monotypic Corallobothrium from the electric catfish, Malapterurus electricus Gmelin, 1789, in Africa and their morphological resemblance is probably a result of convergent evolution (Scholz et al. 2011). In fact, the subfamily Corallobothriinae groups species of unrelated genera (African Corallobothrium in Clade G, three Nearctic genera in Clade I, Japanese Paraproteocephalus in Clade E and Neotropical Megathylacus Woodland, 1934 in Clade D - Fig. 1a, b) that share apparently homoplasious morphological characteristics, i.e. a well-developed metascolex and a medullary position of genital organs as described above (Freze 1965, Rego 1994, Rosas-Valdez et al. 2004).

As a consequence, a new taxon should be proposed to accommodate Nearctic channel catfish proteocephalideans, which are apparently unrelated either to the true corallobothriines (in fact now represented by $C$. solidum and a species to be described, both from Africa) or to the various other proteocephalideans from freshwater teleosts 
in North America that are distributed throughout the phylogenetic tree (Clades $F$ and $D$ - see Fig. 1a, b). Similarly, the position of Paraproteocephalus within the Corallobothriinae will need to be reconsidered. This placement is likely to be due to convergences in scolex shape, and the genus should be placed in the Proteocephaliinae.

\section{Cosmopolitan reptilian proteocephalideans}

The distribution of proteocephalideans in snakes is particularly interesting. Multiple colonizations of reptiles, as already suggested by de Chambrier et al. (2004c), are confirmed here and at least three main events (see Clades $K, N$ and $O$ ) are shown in this study (besides the case of Australotaenia). In each case, cestodes of snakes appear to be related to various proteocephalideans of Neotropical catfishes and other teleosts (Fig. 1a, b). The most interesting novel insight from our study in this context is the strong support found for Clade $K$, composed almost exclusively of parasites from snakes (Viperidae, Elapidae, Lamprophiidae and Xenopeltidae) throughout the world (with the exception of Palearctic) and the unique switch to a mammalian host (Didelphidis marsupialis L., 1758) in the northernmost Neotropical Region in the case of Thaumasioscolex didelphidis. Colubridae are notably absent from this host list. This grouping of rather derived snake parasites cannot be unambiguously explained by our data and may either be the sign of a relatively recent colonization of unrelated groups in all continents or a trace of a very ancient colonization of snakes. Even though all these species belong to the Proteocephalinae because of the medullary position of their genital organs and the absence of a metascolex, they actually differ markedly from each other, especially in their scolex morphology, and were placed in three separate genera (Freze 1965, de Chambrier 1989a, de Chambrier 1989b, Rego 1994, Cañeda-Guzmán et al. 2001, Scholz et al. 2013). Two of these (Macrobothriotaenia Freze, 1965 and Thaumasioscolex) are essentially characterized by peculiar scoleces. The position of Crepidobothrium gerrardii (Monticelli, 1900), a parasite of Boidae that is also characterized by a distinctive scolex, is not fully resolved but is possibly unrelated to this radiation.

Species of Ophiotaenia in colubrids from Holarctic (2 species - Clade O), Neotropical dipsadids (2 species - Clade $N$ ), and Nearctic amphibians are possibly unrelated and appear within a polytomy composed of numerous lineages of Neotropical fish proteocephalideans. They are morphologically uniform and do not differ significantly from the other species of Ophiotaenia in Clade $K$, as all of them have a similar scolex and strobilar morphology, including relative ovary size (see de Chambrier et al. 2012 and Table 1). However, members of the larger radiation (Clade $K$ ) have a Type 1 uterus whereas those in the other clades have a Type 2 uterus. Consequently, and as suspected (Ammann and de Chambrier 2008), it is clear that Ophiotaenia is a composite genus and this name should be restricted to species of Clade $O$, which includes the type species Ophiotaenia perspicua La Rue, 1911 from Neartic colubrids. Species in Clade $O$ have proportionally larger ovaries than those in the remaining species of "Ophiotaenia" (Clades $K, N$ ), which will need to be allocated to other (new) genera. 


\section{"Neotropical fish" superclade}

In addition to the above-mentioned "reptilian" lineages, our derived Clade B is composed of a number of Neotropical parasites of catfishes and a few other teleosts, where the highest species richness can be found in the Pimelodidae (Siluriformes) (de Chambrier and Vaucher 1999, Rego et al. 1999). A few parasites from amphibians and turtles, as well as Proteocephalus perplexus La Rue, 1911 from bowfin (Amia calva L., 1766), also belong to this large polytomy. de Chambrier et al. (2009a) showed that Testudotaenia Freze, 1965 of the monotypic subfamily Testudotaeniinae was part of a North American clade of proteocephalid parasites of fishes despite its distinctive morphology. These results do not contradict this hypothesis although Testudotaenia's closest relatives cannot be inferred from the present tree.

Despite our enlarged sample size, the present study did not resolve the relationships of most Neotropical proteocephalideans from teleosts, and in this respect does not significantly improve the results of Zehnder and Mariaux (1999), de Chambrier et al. (2004c) or Hypša et al. (2005). Still, some nodes are now well supported, e.g., species of Brooksiella Rego, Chubb \& Pavanelli, 1999, Rudolphiella and Cangatiella Pavanelli \& Machado dos Santos, 1991 (Clade J), species of Travassiella Rego \& Pavanelli, 1987, Houssayela Rego, 1987 and two species of "Proteocephalus" (Clade L), and three species of the largely polyphyletic Nomimoscolex, including $N$. piraeeba (type species), together with Jauella glandicephalus (Clade $M$ ). However, these well-supported lineages are composed of species with dissimilar morphologies and often belong to different subfamilies (as many as three in Clade J). In addition, they parasitize fish of different genera, families or even orders, which makes it impossible to define them logically for now.

Other molecular markers, possibly large mtDNA fragments, as used by Waeschenbach et al. (2012), are obviously needed if the internal phylogenetic structure of the derived Clade $B$ is to be unravelled, although the possibility that this node represents a hard-polytomy should also be considered. A similar situation, i.e. support for some of the internal nodes but a lack of support for the major lineages, was observed for the Caryophyllidea, another order of fish tapeworms, despite the use of several nuclear and mitochondrial markers. These commonly employed molecular markers did not contain sufficient phylogenetic signal due to substitution saturation (Brabec et al. 2012).

Catfishes (order Siluriformes) represent one of the key host groups for proteocephalidean cestodes, but there is no obvious coevolutionary pattern between them. This lack of closer host-associations at a higher taxonomic level is not surprising because catfishes form an extraordinarily diverse group of teleosts with over 3,000 valid recognized species (Eschmeyer et al. 2004). The interrelationships of large groups in the Siluroidei, which comprises almost all catfish hosts of proteocephalideans, including the Neotropical pimelodids and heptapterids (Pimelodoidea) and African taxa ("Big Africa" clade with cestode-hosting families Mochokidae, Malapteruridae, and Auchenoglanidae and phylogenetically distant Clariidae) are poorly resolved (Sullivan et al. 2006). Molecular data suggest an ancient siluriform presence, if not origin, in South America, but phylogenies inferred from rag gene sequences did not identify any African-South American catfish clade (Sullivan et al. 2006). 


\section{Monophyly/polyphyly of proteocephalidean genera}

Even though 10 genera (see above) appeared to form monophyletic assemblages, all but one (Proteocephalus aggregate) were represented by a very low number of species (2-3), and the validity of some of them may still have to be reconsidered when a denser sampling is available. In contrast, all species-rich genera with at least nine species analyzed (Nomimoscolex, Ophiotaenia and Proteocephalus sensu lato), as well as Amphoteromorphus (4 species), appeared to be polyphyletic and are distributed across numerous lineages, even though their morphology and host-associations are quite similar.

A situation comparable to that of Proteocephalus (species of this genus belong to at least 7 distinct lineages - Fig. 1a, b) starts to emerge in Nomimoscolex. As previously noted by Zehnder et al. (2000), our Nomimoscolex samples are distributed across several distinct lineages in Clade $D$. The type species $N$. piraeeba, belonging to the well-supported Clade $M$, and all Nomimoscolex loosely grouped across other lineages in Clade D will ultimately have to be placed in other genera. At this point, however, objective morphological characters are still lacking to recognize these worms.

This work also confirms the polyphyly of Monticellia La Rue, 1911 in its present form with M. spinulifera Woodland, 1935 and M. lenha Woodland, 1933 found in siluriforms forming well-supported Clade $P$, which is distantly related to the type species of the genus, $M$. coryphicephala (Monticelli, 1891) from characids. The two former species belong to Monticellia since de Chambrier and Vaucher (1999) synonymised Spasskyellina Freze, 1965 with Monticellia. Spasskyellina was later considered as valid by de Chambrier et al. (2006), without considering the 1999 work, thus generating confusion about the status of the genus. Given the obvious morphological support that confirms our molecular results, we propose splitting Monticellia in order to reflect this situation and to formally resurrect here the genus Spasskyellina, that was erected in 1965 by Freze (Freze 1965) for those taxa possessing gladiate spinitriches (de Chambrier and Scholz 2008, Chervy 2009) on margins of their suckers, i.e. Spasskyellina lenha (Woodland, 1933) Freze, 1965 (type species) and Spasskyellina spinulifera (Woodland, 1935a) Freze, 1965. They are presented under this name in Fig. 1b. Additionally, Spasskyellina mandi Pavanelli \& Takemoto, 1996 is confirmed in this revalidated genus because of its obviously similar morphology, contrary to previous observations (Pavanelli and Takemoto 1996, de Chambrier and Vaucher 1999). Since molecular data for other species of Monticellia are not available, they are provisionally kept in that genus.

\section{Evolution of morphological characters}

Regarding the evolution of morphological characters, the most obvious and evolutionarily important observation derived from Fig. $1 \mathrm{a}, \mathrm{b}$ is the presence of a rostellar apparatus with retractor muscles in all the basal taxa. Such structures (Fig. 3A-C), although with some variation, are characteristic of all Acanthotaeniinae and Gangesiinae and are lost in all more derived Proteocephalidae (Clade A) without exception. Although apical 


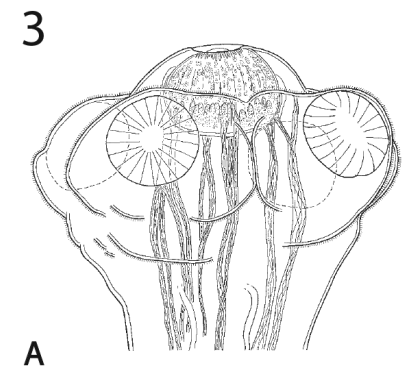

A

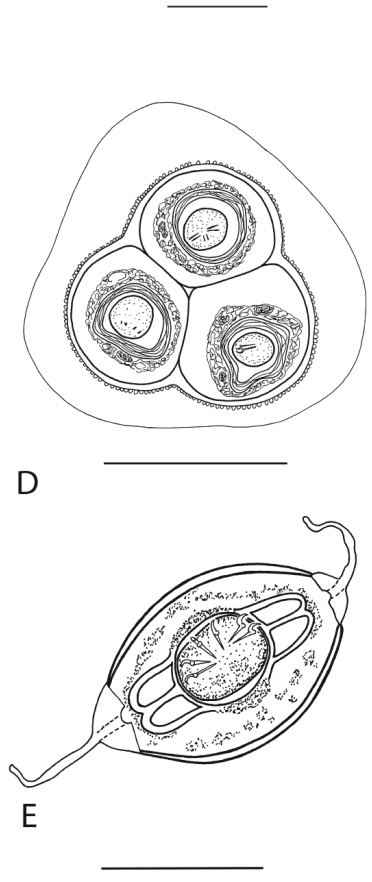

B
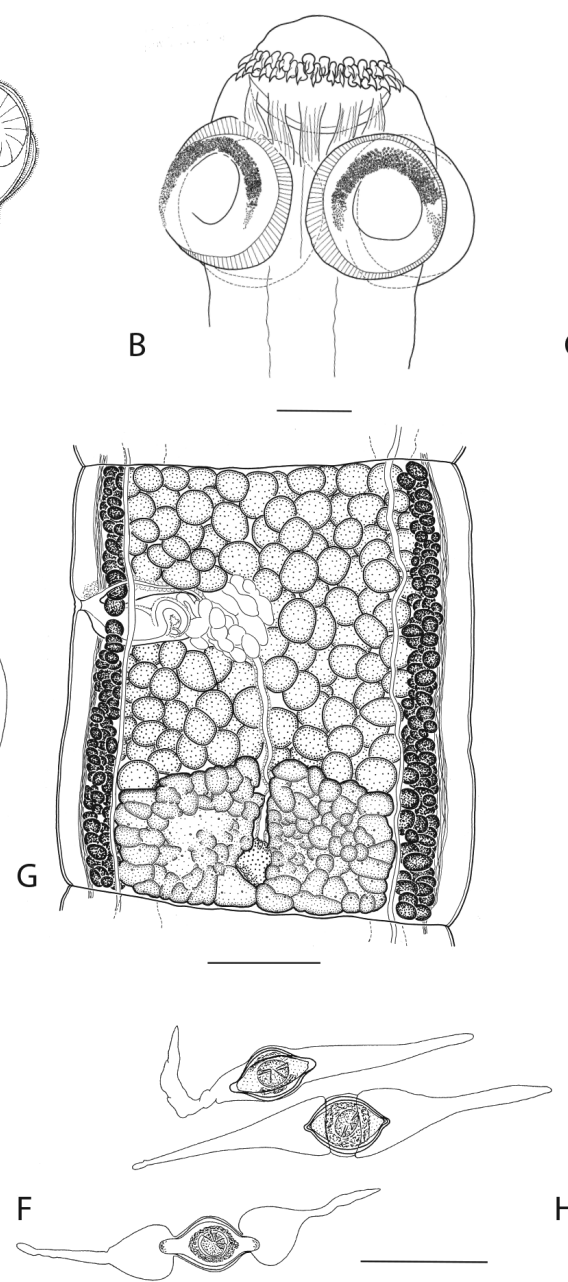

C
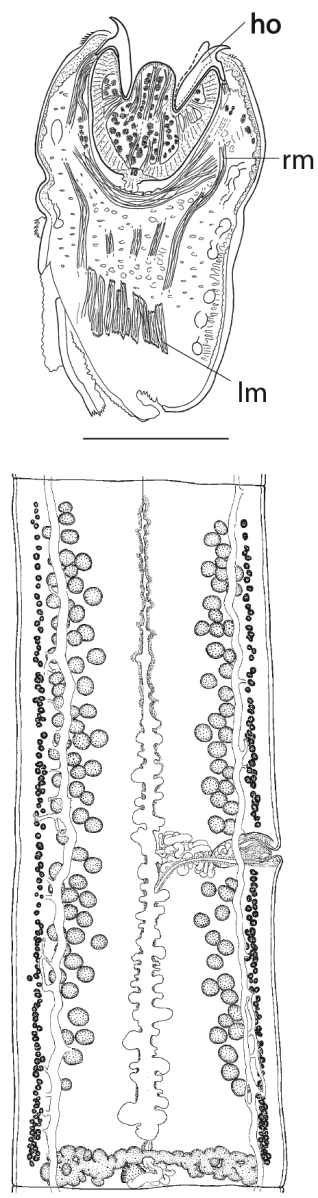

$\mathrm{H}$

Figure 3. A-C Scoleces with rostellum-like organs and retractor muscles. A Without hooks. Ritacestus ritaii (Verma, 1926) (modified from de Chambrier et al. 2011) B With hooks. Gangesia bengalensis (Southwell, 1913) (modified from Ash et al. 2012) C Partly-invaginated. Sagittal section, ho: hooks; rm: retractor muscles; lm; longitudinal muscles. Vermaia pseudotropii (Verma, 1928) (modified from Ash et al. 2010) D-F Egg modifications D Egg cluster in a capsule. Vandiermenia beveridgei (de Chambrier $\&$ de Chambrier, 2010) (modified from de Chambrier and de Chambrier 2010) E Egg with two polar projections. Brooksiella praeputialis (Rego, Santos \& Silva, 1974) (modified from de Chambrier et al. 2004a) F Eggs with two polar projections. Rudolphiella spp. from Calophysus macropterus (two eggs above) and Megalonema platanum, respectively (modified from Gil de Pertierra and de Chambrier 2000) G-H Ovary size G Relatively large ovary (16.4\% proglottid surface) in Gangesia agraensis Verma, 1928 (modified from Ash et al. 2012) H Relatively small ovary in Ophiotaenia lapata Rambeloson, Ranaivoson \& de Chambrier (2012) (2.8\% of proglottid surface) (modified from Rambeloson et al. 2012). Scale-bars: $\mathbf{A}, \mathbf{B}, \mathbf{C}=100 \mu \mathrm{m} ; \mathbf{D}, \mathbf{E}=20 \mu \mathrm{m} ; \mathbf{F}=50 \mu \mathrm{m} ; \mathbf{G}=200 \mu \mathrm{m} ; \mathbf{H}=500 \mu \mathrm{m}$. 
structures are present in some other members of the order such as in the Proteocephalus aggregate from the Holarctic (see Scholz et al. 1998), P. sophiae de Chambrier \& Rego, 1994 from South America, P. glanduligerus (Janicki, 1928) from Africa, Jauella Rego \& Pavanelli, 1985 or Nomimoscolex sensu stricto as defined by Zehnder et al. (2000) (Clade $M)$, these are very different, especially because they lack a supporting muscular apparatus (retractors) (de Chambrier and Rego 1994, de Chambrier and Vaucher 1999, Scholz et al. 2009). This kind of functional simplification, in this case due to the loss of apical attachment structures, is known from other cestode groups and has appeared repeatedly, for example in a number of derived cyclophyllidean genera (Jones et al. 1994), even though these structures are unlikely to be homologous.

The development of the uterus seems to represent one of the key features that reflects the evolution of proteocephalideans and characterizes their major lineages. The evolution of uterine structure as described in de Chambrier et al. (2004c) is essentially supported in the present analysis although with some added complexity. Both putative acquisitions of Type 2 uterine development observed by these authors are observed in our extended analysis (see red circles in Clade $E$ and $D$ ) but the inclusion of new taxa revealed a third instance of transition of this character in Clade I in a well-supported group of Nearctic Corallobothriinae. Furthermore, the situation for taxa belonging to Clade $L$ is unclear with two of them harbouring a Type 2 uterus, one a Type 1 uterus (Travassiella jandia) and one with missing information (gravid proglottids of Proteocephalus kuyukuyu have never been found).

Two basal taxa belonging to Acanthotaeniinae and Gangesiinae show a different, as yet undescribed, form of uterus development that we call "intermediate type" (see purple circles on Fig. 1a). This development differs from Type 1 development by the presence of chromophilic cells at points of origin of the lateral extensions of the uterus before the lateral stems are visible. It differs from Type 2 development in an early appearance of the main tubular uterus axis (Fig. 2). Assuming that the "intermediate type" might be a transitional stage between both uterus development types, a possible interpretation of this observation would be that a general trend toward the acquisition of Type 2 uterus development exists throughout the proteocephalidean diversity.

New morphological characters that are potentially useful for proteocephalidean taxonomy are notoriously difficult to define. However, Ammann and de Chambrier (2008) observed differences in the relative surface area of the ovary in relation to the total surface of the proglottids (see Fig. 3G-H). In their study, this ratio was on average five times lower in 27 species of Ophiotaenia from snakes in the New World compared to Palearctic members of the Proteocephalus aggregate from teleosts. More recently, de Chambrier et al. (2012) compared 66 of the nominal species of Ophiotaenia from Old and New World reptilian hosts with 69 species of Proteocephalus from freshwater teleosts. They noted that the ovaries of species parasitic in non-Palearctic snakes are proportionally smaller than those in species of Proteocephalus parasitic in teleost fishes from all over the world and also considerably smaller than that of congeneric species from European hosts. 
In the present study, data on the relative size of the ovary are provided for all taxa analyzed (see Table 1). Results from two former studies (Ammann and de Chambrier 2008, de Chambrier et al. 2012) are verified here in the context of a larger dataset covering more genera and subfamilies. We can conclude that the ratio of the ovary surface to the proglottid surface in mature proglottids largely corresponds to major host groups and thus represents a promising character of possible phylogenetic importance that should be routinely reported in future descriptions or redescriptions of proteocephalidean taxa (for methodology of taking this ratio - see de Chambrier et al. 2012). However, patterns in the relative size of the ovary of species from different host groups discussed above are not universal and notable exceptions exist. For example, the smallest known ovary is found in Margaritaella gracilis Arredondo \& Gil de Pertierra, 2012 from the catfish Callichthys callichthys (L., 1758) (ratio of 0.6-1.8\%; Arredondo and Gil de Pertierra 2012) and not in a species from snakes.

Characters related to eggs and their morphology have been shown to be important in the systematics of proteocephalidean cestodes (Gil de Pertierra and de Chambrier 2000, Scholz and de Chambrier 2003, de Chambrier et al. 2005, de Chambrier 2006, de Chambrier and de Chambrier 2010, Scholz et al. 2011) but have generally been underexploited and remain poorly known for many species. Here, they allow the characterization of a well-supported node grouping species of Rudolphiella, Brooksiella and Cangatiella (Clade ), because all these taxa possess very typical eggs with polar extensions (Fig. 3E, F). To our knowledge, no other proteocephalidean shows such egg characteristics and thus the presence of polar extensions can be considered as a synapomorphy that defines this group. Furthermore, species in these genera all present a ventral vitellarium and Brooksiella and all species of Rudolphiella (but not Cangatiella) have a folliculate ovary and a metascolex (Gil de Pertierra and Viozzi 1999, de Chambrier et al. 2004b). These morphological characteristics seem to strongly support this clade.

Another kind of egg (in capsules) (Fig. 3D) is found in the basal Australasian $\mathrm{Ka}$ psulotaenia parasites of varanids and is also known in Vandiermenia de Chambrier \& de Chambrier, 2010 and some "Ophiotaenia" of Australian snakes. In the Neotropics a similar evolution of eggs (in groups of 4-6) is known in Thaumasioscolex, the single known proteocephalidean of marsupials. The phylogenetic value of this character remains presently doubtful as some of these worms belong to isolated clades (Scholz et al. 2013). It may however represent an interesting convergent adaption in proteocephalidean with terrestrial life cycle, although it curiously did not seem to have appeared outside of the Autralasian (and maybe Neotropical) region despite the presence of terrestrial proteocephalideans in other areas.

Unfortunately, most lineages revealed in the present study lack such obvious synapomorphies due to a high degree of homoplasy across numerous morphological characters previously used for distinguishing individual genera and subfamilies, such as scolex morphology and the position of reproductive organs in relation to the inner longitudinal musculature (Rego 1994, 1999). Thus, the delineation of many taxonomic groups using morphological features remains currently impossible. 


\section{Conclusions}

This study is based on the most representative molecular dataset of proteocephalidean taxa ever sampled $(33 \%$ of all valid species, almost $80 \%$ of genera and all extant subfamilies). However, some groups are still under-represented, mainly because of the difficulties in obtaining fresh samples, either due to their low prevalence and the protection or rare occurrence of their hosts. Probably the most serious gap in our dataset is the small number (two species) of proteocephalideans parasitizing amphibians (frogs and salamanders). These are usually extremely rare, with less than $1 \%$ of host infected (de Chambrier et al. 2006, Marsella and de Chambrier 2008). Similarly, none of the four species of Ophiotaenia from lizards (excluding Varanus spp.) were available for this analysis. In contrast, our geographical coverage was rather comprehensive thanks to the intensive sampling effort during the last decades. This considerably enlarged dataset has helped to better characterize several lineages, but the relationships of many taxa, especially those in the most derived Clade $B$, largely comprising parasites of catfishes in the Neotropical Region, remain largely unresolved.

The evolutionary history of the order has been apparently much more complicated than one would expect, considering a relatively small number (about 315) of extant species. Although we did not formally examine the host-parasite coevolution of proteocephalideans here, our tree strongly suggests the occurrence of several colonization events of poikilothermic vertebrates as well as repeated colonization of the principal zoogeographical regions with the most recent, and probably explosive, radiation in Neotropical teleosts, especially pimelodid catfishes.

Based on $28 \mathrm{~S}$ rDNA sequences, these results support several new insights into the evolution of proteocephalideans. Unfortunately, they also cast a number of doubts on our present understanding of the classifications within this group: most recognized subfamily-level taxa are, at best, only partially supported. A notable consequence is that scolex morphology and the position of internal organs (testes, uterus and vitelline follicles in relation to the inner longitudinal musculature) should be considered with caution when used for higher-level taxonomy, i.e. to distinguish genera and subfamilies. Clearly a complete taxonomical reorganization of the order is needed. This will likely include the designation of a number of well-supported families and the removal of the subfamilial terminology. Any formal reorganization of the order, however, would be premature as long as a more complete multigene analysis remains to be performed. At lower taxonomical levels, we nevertheless propose resurrecting the genus Spasskyellina for three species of Monticellia (see above) but, for now, we consider that further nomenclatural adaptations should be delayed until clearly supported groups, reinforced by well-defined morphological characters, can be named and adequately characterized.

Results reported herein make it obvious that a new classification should not be based on the characters traditionally used for circumscribing genera and families (Rego 1994). Instead, new synapomorphies should be found to distinguish morphologically similar, but genetically distinct lineages, and to propose a more natural classification that would better reflect the evolutionary history of proteocephalideans. If applied, this 
would represent a clear change of strategy in our attempts to understand the evolution of the group. In practice, this could lead to the erection of numerous small genera consisting of a few species each and sharing only a few morphological, possibly discrete, synapomorphies but with good molecular support. A careful move in that direction might be the future of the systematics and taxonomy of proteocephalideans.

\section{Acknowledgements}

The authors acknowledge the support of NSF PBI awards Nos 0818696 and 0818823 granted to Janine Caira (University of Connecticut) and Kirsten Jensen (University of Kansas). T. S. was supported by the Institute of Parasitology, Biology Centre, CAS (RVO: 60077344) and the Czech Science Foundation (project No. P505/12/G112). A significant part of the material used and sequenced in this study was collected as part of these projects. We also thank the numerous people and institutions over the world who facilitated loans or the organization of collection trips, especially Anirban Ash and Pradip Kumar Kar (Kolkata); Martin Mortenthaler (Iquitos); late Ian Whittington and Leslie Chisholm (Adelaide); David I. Gibson and Eileen Harris (London); late Susan Lim Lee-Hong (Kuala Lumpur); Ian Beveridge (Melbourne); Lester Cannon (Brisbane); Hem Rady (Tonle Sap and Siem Reap); Touch Bunthang (Phnom Penh); Tran Thin Binh (Hanoi), Jeanne Rasamy and Achille Raselimanana (Antananarivo); Abebe Getahun Gubale, Eshete Dejen Dresilign and Moges Beletew (Addis Ababa); Zuheir N. Mahmoud, Ali Adam, Sayed Yousif and Osman Elsheikh (Khartoum), Jean-Paul Gonzalez and Mathieu Bourgarel (Franceville). We acknowledge the contributions of Janik Pralong, Alain Zosso and Gilles Roth (Geneva) for technical assistance, sequencing and for finalising the drawings, respectively. J. M. thanks Yasen Mutafchiev (Sofia) for his help with figures. We thank the staff of the NHM Sequencing Facility (London) for sample processing and sequencing. Thanks are due to Roman Kuchta (České Budějovice) and Rodney A. Bray (London) for their useful reviews of the text.

\section{References}

Ammann M, de Chambrier A (2008) Ophiotaenia gilberti sp. n. (Eucestoda: Proteocephalidea), a parasite of Thamnodynastes pallidus (Serpentes: Colubridae) from Paraguay. Revue Suisse de Zoologie 115:565-573. http://www.biodiversitylibrary.org/page/41184225\#page/113/ mode/lup

Arredondo NJ, Gil De Pertierra A (2012) Margaritaella gracilis gen. n. et sp. n. (Eucestoda: Proteocephalidea), a parasite of Callichthys callichthys (Pisces: Siluriformes) from the Paraná River basin, Argentina. Folia Parasitologica 59: 99-106. doi: 10.14411/fp.2012.015

Ash A, de Chambrier A, Scholz T, Kar PK (2010) Redescription of Vermaia pseudotropii, a hyperapolytic freshwater tapeworm, and composition of Vermaia Nybelin, 1942 (Cestoda: 
Proteocephalidea). Revue Suisse de Zoologie 117: 665-677. http://www.biodiversitylibrary.org/item/148553\#page/113/mode/1up

Ash A, Scholz T, de Chambrier A, Brabec J, Oros M, Kar PK, Chavan SP, Mariaux J (2012) Revision of Gangesia (Cestoda: Proteocephalidea) in the Indomalayan region: morphology, molecules and surface ultrastructure. PLoS ONE 7: e46421. doi: 10.1371/journal. pone. 0046421

Astrin J, Zhou X, Misof B (2013) The importance of biobanking in molecular taxonomy, with proposed definitions for vouchers in a molecular context. ZooKeys 365: 67-70. doi: $10.3897 /$ zookeys.365.5875

Bâ CT, Marchand B (1994) Ultrastructure of the spermatozoon of Sandonella sandoni (Cestoda, Proteocephalidea, Sandonellinae). Invertebrate Reproduction and Development 25: 9-17. doi: 10.1080/07924259.1994.9672363

Bangham RV (1925) A study of the cestode parasites of the black bass in Ohio with special reference to their life history and distribution. Ohio Journal of Science 25: 255-270. https:// kb.osu.edu/dspace/bitstream/handle/1811/2287/V25N06_255.pdf

Batsch AJG (1786) Naturgeschichte der Bandwurmgattung überhaupt und ihrer Arten insbesondere, nach den neueren Beobachtungen in einem systematischen Auszuge. Halle, 298 pp. http://gdz.sub.uni-goettingen.de/en/dms/loader/toc/?PPN=PPN578230488

Brabec J, Scholz T, Králová-Hromadová I, Bazsalovicsová E, Olson PD (2012) Substitution saturation and nuclear paralogs of commonly employed phylogenetic markers in the Caryophyllidea, an unusual group of non-segmented tapeworms (Platyhelminthes). International Journal for Parasitology 42: 259-267. doi: 10.1016/j.ijpara.2012.01.005

Brooks DR (1978) Evolutionary history of the cestode order Proteocephalidea. Systematic Zoology 27: 312-323. doi: 10.2307/2412882

Caira JN, Jensen K, Barbeau E (Eds) (2012) Global Cestode Database. World Wide Web electronic publication. http://www.tapewormdb.uconn.edu/ [accessed 1.III.2015]

Caira JN, Jensen K, Waeschenbach A, Olson PD, Littlewood DT (2014) Orders out of chaos - molecular phylogenetics reveals the complexity of shark and stingray tapeworm relationships. International Journal for Parasitology 44: 55-73. doi: 10.1016/j.ijpara.2013.10.004

Cañeda-Guzmán IC, de Chambrier A, Scholz T (2001) Thaumasioscolex didelphidis n. gen., n. sp (Eucestoda: Proteocephalidae) from the black-eared opossum Didelphis marsupialis from Mexico, the first proteocephalidean tapeworm from a mammal. Journal of Parasitology 87: 639-646. doi: 10.2307/3285105

Chen YH in Dubinina MN (1962) Class Cestoida. In: Bykhovskaya-Pavlovskaya IE, Gusev AV, Dubinina MN, Izyumova NA, Smirnova TS, Sokolovskaya IL, Shtein GA, Shulman SS, Epstein UM (Eds) Key to the parasites of freshwater fishes of the USSR. Nauka, Leningrad, 389-438. [In Russian]

Chervy L (2009) Unified terminology for cestode microtriches: a proposal from the International Workshops on Cestode Systematics in 2002-2008. Folia Parasitologica 56: 199230. doi: 10.14411/fp.2009.025

de Chambrier A (1989a) Révision du genre Crepidobothrium Monticelli, 1900 (Cestoda: Proteocephalidae) parasite d'Ophidiens néotropicaux. I. C. gerrardii (Baird, 1860) et C. viperis 
(Beddard, 1913). Revue Suisse de Zoologie 96: 191-218. http://www.biodiversitylibrary. org/page/41304782\#page/217/mode/1up

de Chambrier A (1989b) Révision du genre Crepidobothrium Monticelli, 1900 (Cestoda: Proteocephalidae) parasite d'Ophidiens néotropicaux. II. C. dollfusi Freze, 1965, C. lachesidis (MacCallum, 1921) et conclusions. Revue Suisse de Zoologie 96: 345-380. http://www. biodiversitylibrary.org/page/41304944\#page/379/mode/1up

de Chambrier A (2001) A new tapeworm from the Amazon, Amazotaenia yvettae gen. n. sp. n. (Eucestoda: Proteocephalidea) from the siluriform fishes Brachyplatystoma filamentosum and B.vaillanti (Pimelodidae). Revue Suisse de Zoologie 108: 303-316. http://www.biodiversitylibrary.org/page/41186945\#page/331/mode/1 up

de Chambrier A (2006) Redescription of Kapsulotaenia sandgroundi (Carter, 1943) (Eucestoda: Proteocephalidea: Acanthotaeniinae), a parasite of Varanus komodoensis (Varanoidea: Varanidae) from Indonesia. Systematic Parasitology 63: 83-93. doi: 10.1007/s11230-005-9001-y de Chambrier A, Al-Kallak SN, Mariaux J (2003) A new tapeworm, Postgangesia inarmata n. sp. (Eucestoda: Proteocephalidea: Gangesiinae), parasitic in Silurus glanis (Siluriformes) from Iraq and some comments on the Gangesiinae Mola, 1929. Systematic Parasitology 55: 199-209. doi: 10.1023/A:1024663120600

de Chambrier A, Binh TT, Scholz T (2012) Ophiotaenia bungari n. sp. (Cestoda), a parasite of Bungarus fasciatus (Schneider) (Ophidia: Elapidae) from Vietnam, with comments on relative ovarian size as a new and potentially useful diagnostic character for proteocephalidean tapeworms. Systematic Parasitology 81: 39-50. doi: 10.1007/s11230-011-9320-0

de Chambrier A, Coquille SC, Brooks DR (2006) Ophiotaenia bonneti sp. n. (Eucestoda: Proteocephalidea), a parasite of Rana vaillanti (Anura: Ranidae) in Costa Rica. Folia Parasitologica 53: 125-133. doi: 10.14411/fp.2006.016

de Chambrier A, Coquille SC, Mariaux J, Tkach V (2009a) Redescription of Testudotaenia testudo (Magath, 1924) (Eucestoda: Proteocephalidea), a parasite of Apalone spinifera (Le Sueur) (Reptilia: Trionychidae) and Amia calva L. (Pisces: Amiidae) in North America and erection of the Testudotaeniinae n. subfam. Systematic Parasitology 73: 49-64. doi: 10.1007/s11230-009-9178-6

de Chambrier A, Mariaux J, Sène A, Mahmoud ZN, Scholz T (2008) Sandonella sandoni (Lynsdale, 1960), an enigmatic and morphologically unique cestode parasitic in the osteoglossiform fish Heterotis niloticus in Africa. Journal of Parasitology 94: 202-211. doi: 10.1645/GE-1275.1

de Chambrier A, Rego AA (1994) Proteocephalus sophiae n. sp. (Cestoda: Proteocephalidae), a parasite of the siluroid fish Paulicea luetkeni (Pisces: Pimelodidae) from the Brazilian Amazon. Revue Suisse de Zoologie 101: 361-368. http://www.biodiversitylibrary.org/ page/41270518\#page/389/mode/1up

de Chambrier A, Rego AA, Gil de Pertierra AA (2005) Redescription of two cestodes (Eucestoda: Proteocephalidea), parasitic in Phractocephalus hemioliopterus (Siluriformes) from the Amazon and erection of Scholzia gen. n. Revue Suisse de Zoologie 112: 735-752. http:// www.biodiversitylibrary.org/page/41226619\#page/167/mode/1up

de Chambrier A, Rego AA, Mariaux J (2004a) Redescription of Brooksiella praeputialis and Goezeella siluri (Eucestoda: Proteocephalidea), parasites of Cetopsis coecutiens (Siluriformes) 
from the Amazon and proposition of Goezeella danbrooksi sp. n. Revue Suisse de Zoologie 111: 111-120. http://www.biodiversitylibrary.org/item/128357\#page/113/mode/1up de Chambrier A, Scholz T (2008) Tapeworms (Cestoda: Proteocephalidea) of firewood catfish Sorubimichthys planiceps (Siluriformes: Pimelodidae) from the Amazon River. Folia Parasitologica 55: 17-28. doi: 10.14411/fp.2008.004

de Chambrier A, Scholz T (2012) A new species of Australotaenia (Cestoda: Proteocephalidea) from a snake in Cambodia: host switching or postcyclic parasitism in a distant region? Folia Parasitologica 59: 279-286. doi: 10.14411/fp.2012.039

de Chambrier A, Scholz T, Beletew M, Mariaux J (2009b) A new genus and species of proteocephalidean (Cestoda) from Clarias catfishes (Siluriformes: Clariidae) in Africa. Journal of Parasitology 95: 160-168. doi: 10.1645/GE-1594.1

de Chambrier A, Scholz T, Ibraheem MH (2004b) Redescription of Electrotaenia malopteruri (Fritsch, 1886) (Cestoda: Proteocephalidae), a parasite of Malapterurus electricus (Siluriformes: Malapteruridae) from Egypt. Systematic Parasitology 57: 97-109. doi: 10.1023/B: SYPA.0000013859.16345.24

de Chambrier A, Scholz T, Mahmoud ZN, Mariaux J, Jirků M (2011) Tapeworms (Cestoda: Proteocephalidea) of Synodontis spp. (Siluriformes) in Africa: survey of species and their redescriptions. Zootaxa 2976: 1-14. http://www.mapress.com/zootaxa/2011/2/ zt02976p014.pdf

de Chambrier A, Vaucher C (1994) Etude morpho-anatomique et génétique de deux nouveaux Proteocephalus (Cestoda: Proteocephalidae), parasites de Platydoras costatus (L.), poisson siluriforme du Paraguay. Systematic Parasitology 27: 173-185. doi: 10.1007/BF00008479

de Chambrier A, Vaucher C (1997) Révision des cestodes (Monticelliidae) décrits par Woodland (1934) chez Brachyplatystoma filamentosum avec redéfinition des genres Endorchis Woodland, 1934 et Nomimoscolex Woodland, 1934. Systematic Parasitology 37: 219-233. doi: 10.1023/A:1005863808627

de Chambrier A, Vaucher C (1999) Proteocephalidae et Monticelliidae (Eucestoda: Proteocephalidea) parasites de poissons d'eau douce au Paraguay, avec descriptions d'un genre nouveau et de dix espèces nouvelles. Revue Suisse de Zoologie 106: 165-240. http://www. biodiversitylibrary.org/page/41267145\#page/183/mode/1up

de Chambrier A, Zehnder M, Vaucher C, Mariaux J (2004c) The evolution of the Proteocephalidea (Platyhelminthes, Eucestoda) based on an enlarged molecular phylogeny, with comments on their uterine development. Systematic Parasitology 57: 159-171. doi: 10.1023/B:SYPA.0000019083.26876.34

de Chambrier S, de Chambrier A (2010) Two new genera and two new species of proteocephalidean tapeworms (Eucestoda) from reptiles and amphibians in Australia. Folia Parasitologica 57: 263-279. doi: 10.14411/fp.2010.033

Diesing KM (1850) Systema helminthum. Wilhelm Braumüller, 680 pp. doi: 10.5962/bhl. title.46846

Dujardin F (1845) Histoire naturelle des helminthes ou vers intestinaux. Librairie Encyclopédique de Roret, Paris, 669 pp. doi: 10.5962/bhl.title.10123

Eschmeyer WN (Ed.) (2015) Catalog of fishes: genera, species, references. http://researcharchive. calacademy.org/research/ichthyology/catalog/fishcatmain.asp [accessed 1.III. 2015] 
Foster PG (2004) P4 - A Python package for Phylogenetics. http://p4.nhm.ac.uk/

Freze VI (1963) [Convergent formation of the rostellum in two branches of Proteocephalata; revision of subfamilies Gangesiinae Mola, 1929 and Acanthotaeniinae Freze, 1963 (Cestoda, Proteocephalata)]. In: Ryzikov KM. Gel'minty cheloveka, zhivotnykhi sel'skokhozyaistvennykh rastenii (k 85-letiyu Akademika K.I. Skryabina). Izdatel'stvo Akademii Nauk, Moscow, 150-155. [In Russian]

Freze VI (1965) [Proteocephalata. Tapeworms of Fish, Amphibians and Reptiles]. In: Skryabin KI (Ed.) [Principles of Cestodology. Vol. 5]. Izdatel'stvo «Nauka«, Moscow, 538 pp. [In Russian] [English translation, Israel Program of Scientific Translation, 1969, Cat. No. 1853. v +597 pp.]

Fritsch G (1886) Die Parasiten des Zitterwelses. Sitzungsberichte der Akademie der Wissenschaften zu Berlin 6: 99-108. http://www.biodiversitylibrary.org/item/93020\#page/119/mode/1up

Fuhrmann O (1916) Eigentümlische Fischcestoden. Zoologischer Anzeiger 46: 385-398. http://www.biodiversitylibrary.org/page/29985893\#page/395/mode/1 up

Gil de Pertierra AA, de Chambrier A (2000) Rudolphiella szidati sp. n. (Proteocephalidea: Monticelliidae, Rudolphiellinae) parasite of Luciopimelodus pati (Valenciennes, 1840) (Pisces: Pimelodidae) from Argentina with new observations on Rudolphiella lobosa (Riggenbach, 1895). Revue Suisse de Zoologie 107: 81-95. http://www.biodiversitylibrary. org/page/41280220\#page/99/mode/1up

Gil de Pertierra AA, Viozzi GP (1999) Redescripción de Cangatiella macdonaghi (Szidat y Nani, 1951) comb. nov. (Cestoda: Proteocephalidae) un parásito del pez ateriniforme Odontesthes hatcheri (Eigenmann, 1909) de la región patagónica de Argentina. Neotropica 45: 13-20.

Hypša V, Škeř́ková A, Scholz T (2005) Phylogeny, evolution and host-parasite relationships of the order Proteocephalidea (Eucestoda) as revealed by combined analysis and secondary structure characters. Parasitology 130: 359-371. doi: 10.1017/S0031182004006638

Janicki C (1928) Cestodes s. str. aus Fischen und Amphibien. Results of the Swedish zoological expedition to Egypt and the White Nile 1901 under the direction of L. A. Jägerskiöld. The Library of the Royal University of Uppsala, Uppsala, 58 pp.

Jones A, Bray RA, Khalil LF (1994) Order Cyclophyllidea van Beneden in Braun, 1900. In: Khalil LF, Jones A, Bray RA (Eds) Keys to the cestode parasites of vertebrates. CAB International, Wallingford, 305-307.

Jones AW, Kerley C, Sneed KE (1956) New species and a new subgenus of Corallobothrium (Cestoda, Proteocephala) from catfishes of the Mississippi basin. Journal of the Tennessee Academy of Science 31: 179-185. http://iweb.tntech.edu/sstedman/JTAS 31-3.pdf

Khalil LF (1960) On a new genus, Sandonella, for Proteocephalus sandoni Lynsdale, 1960, (Proteocephalidae) and the erection of a new subfamily, Sandonellinae. Journal of Helmintholology 34: 47-54. doi: 10.1017/S0022149X00020332

La Rue GR (1909) On the morphology and development of a new cestode of the genus Proteocephalus Weinland. Transactions of the American Microscopical Society 28: 17-49. doi: $10.2307 / 3220970$

La Rue GR (1911) A revision of the cestode family Proteocephalidae. Zoologischer Anzeiger 38: 473-482. http://www.biodiversitylibrary.org/item/95304\#page/485/mode/1 up 
Lundberg JG, Littmann MW (2003) Pimelodidae (long-whiskered catfishes). In: Reis RE, Kullander SO, Ferraris Jr CJ (Eds) Checklist of the Freshwater Fishes of South and Central America. EDIPUCRS, Porto Alegre, 432-446.

Lundberg JG, Sullivan JP, Hardman M (2011) Phylogenetics of the South American catfish family Pimelodidae (Teleostei: Siluriformes) using nuclear and mitochondrial gene sequences. Proceedings of the Academy of Natural Sciences of Philadelphia 161: 153-189. doi: $10.1635 / 053.161 .0110$

Lynsdale JA (1960) On Proteocephalus sandoni n. sp. from the Sudan. Journal of Helminthology 34: 43-46. doi: 10.1017/S0022149X00020320

Magath TB (1924) Ophiotaenia testudo, a new species from Amyda spinifera. Journal of Parasitolology 11: 44-49. doi: 10.2307/3271129

Marsella CMV, de Chambrier A (2008) Ophiotaenia alessandrae sp. n. (Eucestoda: Proteocephalidea), a parasite of Hyla boans (Anura: Hylidae) from Amazonia in Ecuador. Revue Suisse de Zoologie 115: 553-563. http://www.biodiversitylibrary.org/page/41184237\#page/ $125 /$ mode/1up

Meggitt FJ (1931) On cestodes collected in Burma. Part II. Parasitology 23: 250-263. doi: $10.1017 /$ S0031182000013615

Monticelli F (1891) Noticie su di alcune specie di Taenia. Bollettino della Società dei naturalisti in Napoli 5: 151-174. http://www.biodiversitylibrary.org/item/92741\#page/161/ mode/1up

Monticelli F (1900) Sul Tetrabothrium gerrardii Baird. Atti della Società dei naturalisti e matematici di Modena 32: 9-26. http://www.biodiversitylibrary.org/item/95750\#page/23/mode/1 up Nylander JAA (2004) MrModeltest v2. Program distributed by the author. Evolutionary Biology Centre, Uppsala University. https://www.abc.se/ - nylander/

Olson PD, Littlewood DTJ, Bray RA, Mariaux J (2001) Interrelationships and evolution of the tapeworms (Platyhelminthes: Cestoda). Molecular Phylogenetics and Evolution 18: 443-467. doi: 10.1006/mpev.2001.0930

Osler CP (1931) A new cestode from Rana clamitans Latr. Journal of Parasitolology 17: 183186. http://www.jstor.org/stable/3271453

Pavanelli GC, Machado dos Santos MH (1991) Proteocefalideos parasitas de peixes, em especial pimelodideos, do Rio Paraná, Paraná. UNIMAR 13: 163-175.

Pavanelli GC, Rego AA (1989) Novas espécies de proteocefalídeos (Cestoda) de Hemisorubim platyrhynchos (Pisces-Pimelodidae) do estado do Paraná. Revista Brasileira de Biologia 49: 381-386.

Pavanelli GC, Takemoto RM (1996) Spasskyellina mandi n. sp. (Proteocephalidea: Monticelliidae), a parasite of Pimelodus ornatus Kner, 1857 (Pisces: Pimelodidae) of the Paraná River, Paraná, Brazil. Memorias do Instituto Oswaldo Cruz 91: 723-726. http://memorias-old. ioc.fiocruz.br/916/3125.pdf

Rambeloson VR, Ranaivoson HC, de Chambrier A (2012) Ophiotaenia lapata sp. n. (Eucestoda: Proteocephalidea) from Madagascar: a parasite of the endemic snake Madagascarophis colubrinus (Colubridae). Revue Suisse de Zoologie 119: 547-559.

Rego AA (1984) Proteocephalidea from Amazonian freshwater fish: new systematic arrangement for the species described by Woodland as Anthobothrium (Tetraphyllidea). Acta Amazonica 14: 86-94. 
Rego AA (1987) Taxonomic reorganization of proteocephalid cestodes from Brazil. Revista Brasileira de Biologia 47: 203-212.

Rego AA (1994) Order Proteocephalidea Mola, 1928 In: Khalil LF, Jones A, Bray RA (Eds) Keys to the cestode parasites of vertebrates. CAB International, Wallingford, 257-293.

Rego AA (1995) A new classification to the cestode order Proteocephalidea Mola. Revista Brasileira de Zoologia 12: 791-814. doi: 10.1590/S0101-81751995000400009, http://www. scielo.br/pdf/rbzool/v12n4/v12n4a09.pdf

Rego AA (1999) Scolex morphology of proteocephalid cestode parasites of Neotropical freshwater fishes. Memorias do Instituto Oswaldo Cruz 94: 37-52. doi: 10.1590/s007402761999000100011

Rego AA, de Chambrier A, Hanzelová V, Hoberg E, Scholz T, Weekes P, Zehnder M (1998) Preliminary phylogenetic analysis of subfamilies of the Proteocephalidea (Eucestoda). Systematic Parasitology 40: 1-19. doi: 10.1023/A:1005903506363

Rego AA, Chubb JC, Pavanelli GC (1999) Cestodes in South American freshwater teleost fishes: keys to genera and brief description of species. Revista Brasileira de Zoologia 16: 299-367. doi: 10.1590/S0101-81751999000200003, http:/www.scielo.br/pdf/rbzool/ v16n2/v16n2a03.pdf

Rego AA, Ivanov V (2001) Pseudocrepidobothrium eirasi gen. n. and comb. nov., parasite of a South American freshwater fish, and comparative cladistic analysis with Crepidobothrium spp. Acta Scientiarum 23: 363-367.

Rego AA, Machado PM, Pavanelli GC (1999) Sciadocephalus megalodiscus Diesing, 1850 (Cestoda: Corallobothriinae), a parasite of Cichla monoculus Spix, 1831 (Cichlidae), in the Paraná river, State of Paraná, Brazil. Journal of the Helminthological Society of Washington 66: 133-137. http://bionames.org/bionames-archive/issn/1049-233X/66/133.pdf

Rego AA, Pavanelli GC (1985) Jauella glandicephalus gen. n., sp. n. e Megathylacus brooksi sp. n., cestoides patogenicos para o jau, Paulicea luetkeni, peixe pimelodideos. Revista Brasileira de Biologia 45: 643-652.

Rego AA, Pavanelli GC (1987) Cestoides proteocephalideos do jau, Paulicea luetkeni, peixe pimelodideo do Brasil. Revista Brasileira de Biologia 47: 357-361.

Rego AA, dos Santos JC, Silva PP (1974) Estudos de cestoides de peixes do Brasil. Memorias do Instituto Oswaldo Cruz 72: 187-204. doi: 10.1590/S0074-02761974000200004, http:// www.scielo.br/pdf/mioc/v72n3-4/tomo72(f3-4)_042-059.pdf

Ronquist F, Huelsenbeck JP (2003) MrBayes 3: Bayesian phylogenetic inference under mixed models. Bioinformatics 19: 1572-1574. doi: 10.1093/bioinformatics/btg180

Rosas-Valdez R, Choudhury A, Pérez-Ponce de León G (2004) Phylogenetic analysis on genera of Corallobothriinae (Cestoda: Proteocephalidea) from North American ictalurid fishes, using partial sequences of the 28S ribosomal gene. Journal of Parasitology 90: 1123-1127. doi: $10.1645 / \mathrm{GE}-268 \mathrm{R}$

Ruedi V, de Chambrier A (2012) Pseudocrepidobothrium ludovici sp. n. (Eucestoda: Proteocephalidea), a parasite of Phractocephalus hemioliopterus (Pisces: Pimelodidae) from Brazilian Amazon. Revue Suisse de Zoologie 119: 137-147.

Scholz T, de Chambrier A (2003) Taxonomy and biology of proteocephalidean cestodes: current state and perspectives. Helminthologia 40: 65-78. 
Scholz T, de Chambrier A (2012) A new genus and species of proteocephalidean tapeworm (Cestoda) from Pangasius larnaudii (Siluriformes: Pangasiidae) in Southeast Asia. Journal of Parasitology 98: 648-653. doi: 10.1645/GE-2992.1

Scholz T, de Chambrier A, Beletew M, Mahmoud ZN (2009) Redescription of Proteocephalus glanduligerus (Cestoda: Proteocephalidea), a parasite of clariid catfishes in Africa with a unique glandular apical organ. Journal of Parasitology 95: 443-449. doi: 10.1645/GE1715.1

Scholz T, de Chambrier A, Kuchta R, Littlewood DTJ, Waeschenbach A (2013) Macrobothriotaenia ficta (Cestoda: Proteocephalidea), a parasite of sunbeam snake (Xenopeltis unicolor): example of convergent evolution. Zootaxa 3640: 485-499. doi: 10.11646/zootaxa.3640.3.12

Scholz T, de Chambrier A, Mariaux J, Kuchta R (2011) Redescription of Corallobothrium solidum (Cestoda: Proteocephalidea) and erection of a new genus, Essexiella, for tapeworms from channel catfishes (Ictaluridae). Journal of Parasitology 97: 1142-1151. doi: 10.1645/ GE-2705.1

Scholz T, Drábek R, Hanzelová V (1998) Scolex morphology of Proteocephalus tapeworms (Cestoda: Proteocephalidae), parasites of freshwater fish in the Palaearctic Region. Folia Parasitologica 45: 27-43.

Scholz T, Hanzelová V (1998) Tapeworms of the genus Proteocephalus Weinland, 1858 (Cestoda: Proteocephalidae), parasites of fishes in Europe. Academia, Prague, 118 pp.

Scholz T, Hanzelová V, Škeř́ková A, Shimazu T, Rolbiecki L (2007) An annotated list of species of the Proteocephalus Weinland, 1858 aggregate sensu de Chambrier et al. (2004) (Cestoda: Proteocephalidea), parasites of fishes in the Palaearctic Region, their phylogenetic relationships and a key to their identification. Systematic Parasitology 67: 139-156. doi: 10.1007/s11230-006-9089-8

Scholz T, Ždárská Z, de Chambrier A, Drábek R (1999) Scolex morphology of the cestode Silurotaenia siluri (Batsch, 1786) (Cestoda: Gangesiinae), a parasite of European wels (Silurus glanis). Parasitology Research 85: 1-6. doi: 10.1007/s004360050498

Škeř́ková A, Hypša V, Scholz T (2001) Phylogenetic analysis of European species of Proteocephalus (Cestoda: Proteocephalidea): compatibility of molecular and morphological data, and parasite-host coevolution. International Journal for Parasitology 31: 1121-1128. doi: 10.1016/S0020-7519(01)00226-0

Sullivan JP, Lundberg JG, Hardman M (2006) A phylogenetic analysis of the major groups of catfishes (Teleostei: Siluriformes) using rag1 and rag2 nuclear gene sequences. Molecular Phylogenetics and Evolution 41: 636-662. doi: 10.1016/j.ympev.2006.05.044

Verma SC (1926) On a new proteocephalid cestode from an Indian fresh-water fish. Allahabad University Studies 2: 353-362.

Verma SC (1928) Some cestodes from the Indian fishes, including four new species of Tetraphyllidea and revised keys to the genera Acanthobothrium and Gangesia. Allahabad University Studies 4: 119-176.

Waeschenbach A, Webster BL, Littlewood DT (2012) Adding resolution to ordinal level relationships of tapeworms (Platyhelminthes: Cestoda) with large fragments of mtDNA. Molecular Phylogenetics and Evolution 63: 834-847. doi: 10.1016/j.ympev.2012.02.020 
Wedl K (1861) Zur Helminthenfauna Aegyptens (1 Abt.). Sitzungsberichte aus der Kaiserliche Akademie der Wissenschaften Wien 44: 463-482.

Weinland DF (1858) Human cestoides. An essay on the tapeworms of man. Metcalf and Company, Cambridge, $\mathrm{x}+93 \mathrm{pp}$.

Wilkinson M (1996) Majority-rule reduced consensus trees and their use in bootstrapping. Molecular Biolology and Evolution 13: 437-444. doi: 10.1093/oxfordjournals.molbev. a025604

Woodland WNF (1924) On a new Bothriocephalus and a new genus of Proteocephalidae from Indian fresh-water fishes. Parasitology 16: 441-451. doi: 10.1017/S0031182000020345

Woodland WNF (1933) On a new subfamily of proteocephalid cestodes - the Othinoscolecinae - from the Amazon siluroid fish Platystomatichthys sturio (Kner). Parasitology 25: 491-500. doi: 10.1017/S0031182000019739

Woodland WNF (1934a) On some remarkable new cestodes from the Amazon siluroid fish, Brachyplatystoma filamentosum (Lichtenstein). Parasitology 26: 268-277. doi: 10.1017/ S0031182000023556

Woodland WNF (1934b) On six new cestodes from Amazon Fishes. Proceedings of the Zoological Society London 104: 33-44. doi: 10.1111/j.1469-7998.1934.tb06218.x

Woodland WNF (1935a) Additional cestodes from the Amazon siluroids pirarara, dorad, and sudobim. Proceedings of the Zoological Society of London 104: 851-862. doi: 10.1111/ j.1096-3642.1934.tb01669.x

Woodland WNF (1935b) Some more remarkable cestodes from Amazon siluroid fish. Parasitology 27: 207-225. doi: 10.1017/S0031182000015080

Woodland WNF (1935c) Some new proteocephalids and a ptychobothriid (Cestoda) from the Amazon. Proceedings of the Zoological Society of London 105: 619-623. doi: 10.1111/ j.1096-3642.1935.tb01685.x

Wu M, Chatterji S, Eisen JA (2012) Accounting for alignment uncertainty in phylogenomics. PLoS ONE 7: e30288. doi: 10.1371/journal.pone.0030288

Zehnder MP, de Chambrier A (2000) Morphological and molecular analyses of the genera Peltidocotyle Diesing 1850 and Othinoscolex Woodland 1933, and morphological study of Woodlandiella Freze, 1965 (Eucestoda,Proteocephalidea), parasites of South American siluriform fishes (Pimelodidae). Systematic Parasitology 46: 33-43. doi: 10.1023/A:1006252601201

Zehnder MP, de Chambrier A, Vaucher C, Mariaux J (2000) Nomimoscolex suspectus n. sp. (Eucestoda: Proteocephalidea: Zygobothriinae) with morphological and molecular phylogenetic analyses of the genus. Systematic Parasitology 47: 157-172. doi: 10.1023/A:1006465026316

Zehnder MP, Mariaux J (1999) Molecular systematic analysis of the order Proteocephalidea (Eucestoda) based on mitochondrial and nuclear rDNA sequences. International Journal for Parasitology 29: 1841-1852. doi: 10.1016/S0020-7519(99)00122-8 


\section{Supplementary material I}

\section{Figure 1}

Authors: Alain de Chambrier, Andrea Waeschenbach, Makda Fisseha, Tomáš Scholz, Jean Mariaux

Data type: Phylogenetic tree

Explanation note: Bayesian inference of partial (domains 1-3) 28S rDNA sequences of the complete taxon set of proteocephalideans performed using MrBayes version 3.1 using the GTR + I + G model of sequence evolution. Two parallel runs were performed for 10,000,000 generations; 8,000,000 generations were discarded as burnin. Branches with posterior probability (pp) support below 95\% are collapsed; pp are indicated below branches.

Copyright notice: This dataset is made available under the Open Database License (http://opendatacommons.org/licenses/odbl/1.0/). The Open Database License $(\mathrm{ODbL})$ is a license agreement intended to allow users to freely share, modify, and use this Dataset while maintaining this same freedom for others, provided that the original source and author(s) are credited.

\section{Supplementary material 2}

\section{Table 1}

Authors: Alain de Chambrier, Andrea Waeschenbach, Makda Fisseha, Tomáš Scholz, Jean Mariaux

Data type: Leaf stability test results

Explanation note: Leaf stability test results from the post-burnin posterior tree distribution from two MrBayes runs that included the full complement of taxa. Taxa are ranked based on their positional stability estimated from the Maximum, which is an average of all the highest percentages from all possible quartet sets for a particular taxon, Difference, which is the difference between the highest and the second highest percentages from all possible quartet sets for a particular taxon, and Entropy, which is calculated as the normalized sum of logs for each quartet percentages (except the unresolved polygamy).

Copyright notice: This dataset is made available under the Open Database License (http://opendatacommons.org/licenses/odbl/1.0/). The Open Database License $(\mathrm{ODbL})$ is a license agreement intended to allow users to freely share, modify, and use this Dataset while maintaining this same freedom for others, provided that the original source and author(s) are credited. 